\title{
Energy Flow through the Common Hamster Population
}

\author{
Andrzej GORECKI
}

Górecki A., 1977: Energy flow through the common hamster population. Acta theriol., 22, 2: 25-66 [With 9 Tables \& 11 Figs.]).

A study of the energy flow through a population of the common hamster Cricetus cricetus ( $\mathrm{L}$ in naeus, 1758) and its impact on crops was carried out in cultivated fields, 128 ha in area, in the Vistula valley, about $80 \mathrm{~km}$ east of Cracow. The population dynamics of these rodents, their activity rhythm, and the climatic parameters were determined in a field study. The average daily metabolic rate (ADMR) and chemical thermoregulation $(R M R)$ were measured in the laboratory, where the composition of their natural diet and the consumption and utilization of foods were also estimated. The number of adult hamsters was determined by counting active burrows in the spring and autumn of each year. The mean annual density of adult hamsters was $8.5 / \mathrm{ha}$. After the inclusion of young animals, the number of which was estimated from the number of embryos, the total annual density is on the average 12.4 hamsters/ha. The daily energy budget $(D E B)$ of an average hamster in each month of the year was calculated from the measurements of the dependence of $A D M R$ upon body weight, $R M R$, and the data on metabolism during hibernation obtained from literature. $D E B$ reaches the highest level in the months of activity (on the average about $40 \mathrm{kcal} / \mathrm{animal}$ day). $D E B$ fluctuates between 11 and $30 \mathrm{kcal} / \mathrm{ani}-$ mal day during hibernation. The whole population dissipates a total of $1.44 \times 10^{5} \mathrm{kcal} / \mathrm{ha}$ year for the cost of maintenance (respiration), $83 \%$ of which in the period of active life. The production of the population is $1.12 \times 10^{4} \mathrm{kcal} / \mathrm{ha}$ year and its efficiency in relation to assimilation is $7.2 \%$. The impact exerted on crops by the summer consumption of hamsters is small and constitutes less than $1 \%$. On the other hand, the losses caused in crops by their consumption in the autumn and chiefly by the gathering of food supplies (about $15 \mathrm{~kg} / \mathrm{animal}$ ), reach $6 \%$ and are the more important, because they mainly affect the final crop, i.e. grain.

[Dept. Anim. Ecol., Jagiellonian Univ., Krupnicza 50, 30-060 Kraków].

\section{INTRODUCTION}

Recent observations have provided a large number of data necessary to estimate the energy flow through animal populations. As regards mammals, particularly much information in this respect has been gathered about many rodent (Grodzinski, Klekowski \& Duncan, 1975: Golley, Petrusewicz \& Ryszkowski, 1975) and ungulate

1 Praca została wykonana $w$ ramach problemu węzłowego 09.1.7, koordynowanego przez Instytut Ekologii PAN. 
(Grodzinski \& Pucek, 1975) species. It should however be emphasized that all these papers are, as a rule, concerned with species that are active continuously all through their lives.

However, there are a great many periodically active mammals. Their significance is indicated by the fact that, out of the about 100 species living in Poland ( $\mathrm{Kow}$ als ki, 1964), more than 40 species "withdraw" from active life for a variously long time either in the daily or in the annual cycle. In addition to hibernators, this group includes estivating species and such as can change their metabolism very considerably during the 24-hour period, e.g. bats, which occur in large numbers in the Polish fauna, or some small rodents. The flow of energy through the animals included in this group is incomparably worse known and even then in hardly a few species (K a yser, 1939, 1961; Gę bczyński, Górecki \& Drózd ż, 1972).

The periodically active animals, notably the hibernating species, differ completely from the continuously active animals in their influence upon the ecosystem, because the hibernators survive the whole year at the cost of energy stored in the form of their own tissue or food supplies. This storage of energy must be completed in the relatively short period of their active life. The deposition of tissues is rather an energetic process (B I a x t e r, 1966; K ing \& Farner, 1961) and it raises the energetic expenses of animals. In the same period of active life the animals must, in addition, bear the very high cost of reproduction ( $\mathrm{Kaczmarski}$, 1966; Trojan \& Wojciechowska, 1967; Migula, 1969).

The common hamster Cricetus cricetus ( $\mathrm{L}$ in na e us, 1758) is a rodent species, which is active for only a part of the year and its body weight often exceeds $800 \mathrm{~g}$. The range of this animal covers the whole steppe region of Eastern Europe and in Asia it extends as far as the Yenisey. In Europe the range of the common hamster is discontinuous, in the west and south it reaches Belgium, France, Switzerland, Yugoslavia and Rumania (Kow a l s ki, 1964) and the northern borderline of its distribution runs across FRG, GDR, and Poland. In Poland common hamsters inhabit the southern and central parts of the country except the Carpathians ( $\mathrm{S} \mathrm{u} \mathrm{rdacki}, 1963,1971,1973$ ). They live nearly exclusively in meadows and cultivated fields. Being for the most part plant-eaters ( $\mathrm{S} \mathrm{urdacki}$ i 1964; Gor e c$\mathrm{ki} \&$ Grygielska, 1975), which gather proverbial winter food supplies (Feriancova-Masarova \& Hanak, 1965; Walker, 1964), the hamsters may cause damage to crops, the more so, because building their extensive burrows, they impede the mechanical cultivation of the soil. An additional feature is the fact that, although hamsters are not marked by typical mass outbreaks, they maintain the mean size of population at a relatively high level.

The ecology and biology of this species is known only fragmentarily (Petzsch, 1952; Walker, 1964; Karaseva \& Shilayeva, 1965; Samoš, 1975; Vohrali $\mathrm{k}, 1974,1975)$. Owing to their wide range, hamsters were used as models of hibernating mammals. In this context the physiological data concerning these animals are for the most part limited to the period of hibernation ( $\mathrm{K}$ a y s er, 1939, 1959, 1971; L y man \& Dawe, 1960), whereas only little is known about their physiolo- 
gical features during the period of active life, this being chiefly information on the consumption ( $\mathrm{S} \mathrm{r} \mathrm{dacki}, 1964$ ) and utilization food by hamsters ( $\mathrm{Erdakov}$, 1972; Górecki \& Grygielska, 1975). Similarly, little information is available on the metabolism and thermoregulation of hamsters ( $\mathrm{K}$ a y s e r, 1959, 1961; V is i nescu, 1968; M a la n \& Hildwein, 1969; Gorecki \& Wolek, 1975) or their activity (Canguillem, Schieber \& Koch, 1973; Weiner \& Gorecki, 1974).

In order to evaluate the flow of energy through the population of these animals and to estimate their role in the ecosystems of cultivated fields quantitatively, it was indispensable to get to know the missing links in their physiological, bioenergetic and population parameters. The purpose of the present work was to collect data concerning (a) the size and demographic parameters of a hamster population and (b) the growth rate and body weight of these animals. The 24-hour activity rhythm and the length of stay of hamsters out of their burrows were determined under field conditions. The daily metabolism and chemical thermoregulation were measured in the laboratory. The composition of food consumed and its utilization were also determined and the data on thermal conditions under which the study population lived were noted.

All the information obtained in this way made it possible not only to estimate the dynamics of the population size and some physiological indices of this rodent, but also to calculate the flow of energy through the whole population. Apart from this it became possible to determine, in part, the economic significance of the common hamster and the damage caused by it. This study, as a whole, enabled us also to grasp the differences between the rodents which are periodically and those permanently active.

\section{MATERIAL AND METHODS}

The present study of the energy flow through a hamster population was carried out during four successive years (1971-1974), applying both field and laboratory methods. All the field investigations were conducted in the fields of the Experimental Station, Institute of Tillage, Fertilization and Pedology, at Borusowa, about $80 \mathrm{~km}$ east of Cracow. At first the study covered an area of 200 ha and from the end of 1971 six complexes of fields of a total area of 128 ha. They were isolated from other fields by the embankment of the Vistula on one side and nearly completely by the buildings of the villages Borusowa and Karsy on the remaining three sides (Fig. 1).

The soils of these fields are silts on the substratum of loose sands and those with underlying clay. Despite the vicinity of the Vistula the water table is rather low; there was no water at the depth reached by the deepest burrows of hamsters more than $2 \mathrm{~m}$. The main crops were wheat, maize, lucerne, rape, potatoes and sugar-beets; the singular fields did not, as a rule, exceed $20-25$ ha in area. There were only very few trees amidst the fields. Dogs and a very small number of foxes were natural predators of hamsters in the study area.

The study was carried out in three complexes of fields each area comprising $50-70$ ha the number of animals being estimated and observations made in two 
of them (Fig. 1, fields Nos. 1 and 2). All captures were made in the control field (No. 3).

The number of hamsters was estimated twice each year: in spring, immediately after the hamsters had left their burrows, and in autumn, just before the hibernation season. The number was determined by counting the burrows in several to more than ten transects, 5 by $150 \mathrm{~m}$ each. The whole area in which the burrows. were counted was generally 2-7\% (averaging $3.5 \%$ ) of the area under a given crop (Table 1). All the estimations were made simultaneously in two or three consecutive days over the whole area of 128 ha so as to eliminate the influence of migrations of hamsters from one field to another at the time of counting.

Common hamsters generally live singly throughout the year with the one exception being that of nursing females (S a m o s, 1975; P et z s ch, 1952). In addition to its main burrow, usually with several entrances, each hamster has a few other burrows used as hiding-places in a case of danger. They are scattered all over its.

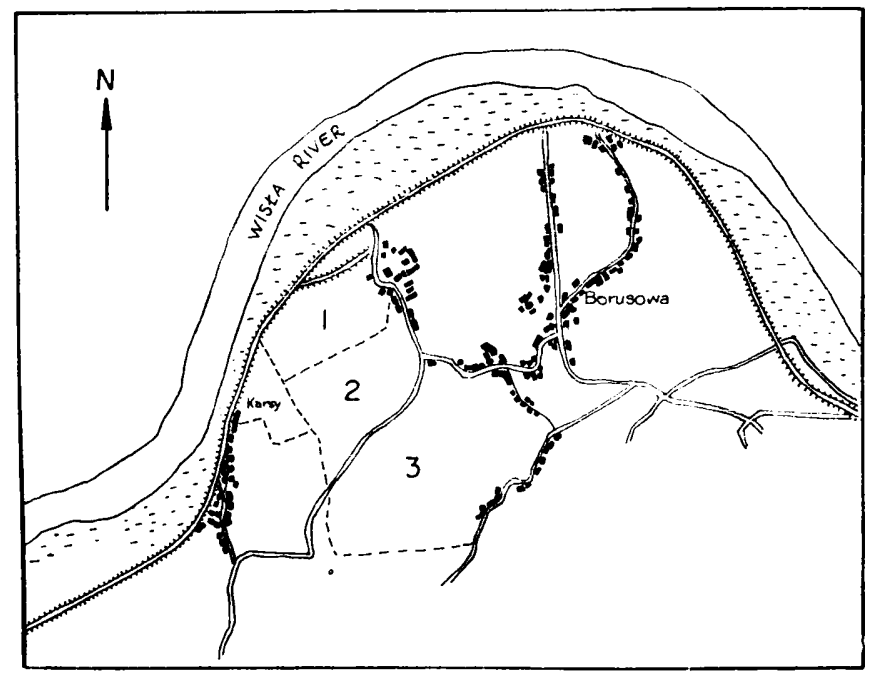

Fig. 1. Situation of the study area.

1,2 - fields in which dynamics of the number of hamsters was studied, 3 - control field, in which captures were made.

individual territory (Karaseva \& Shil a y eva, 1965). For this very reason, the number of burrows (burrow entrances) falling to one animal was determined both in the spring and in the autumn. The method used was that described by $\mathrm{Su} \mathrm{r} \mathrm{d} \mathrm{a} \mathrm{cki}$ (1968). At about 5 a.m. the entrances of 50-70 burrows were stopped with straw. The size of the plots investigated in this way naturally depended on the number of burrows and usually approximated $50 \times 50 \mathrm{~m}$. After 12 hours, and then in the evening of the same day, and after 24 hours (in connection with the 24-hour activity rhythm of hamsters) opened burrows were counted. The mean from the two counts of opened burrows was used to calculate the ratio of the number of opened burrows to that of closed ones. The index thus calculated was later used to compute the number of hamsters and the number of active burrows in the study area in the given season.

In order to find the age and sex structures of the population and to perform all 
the laboratory determinations and measurements, hamsters were captured by the method of flooding their burrows (Andrzejewski \& Gliwicz, 1969). A water-cart, $2000 \mathrm{l}$ in capacity, pulled by a tractor, was usually applied for this purpose. A total of about 450 hamsters were captured over the study period.

The age of animals $(n=85)$ was determined on the basis of their body weights and the weight of eye lenses fixed in $10 \%$ formalin and dried up by $L$ or d's method (1959).

The 24-hour activity of hamsters was studied by recording the number of passes of hamsters coming into and going out of the burrow, thereby interrupting a beam of infra-red light (W e in e r \& Go recki, 1974). This investigation was carried out in summer and autumn for two years (1973-1974). Altogether, activity was recorded in 153 days and nights.

During the period of 1971-1974 meteorological data were recorded in the station situated in the field where the hamster population was studied. Temperature was measured $2 \mathrm{~m}$ above, $50 \mathrm{~cm}$ below and at the surface of the ground. Rainfall was also noted.

In laboratory experiments the average daily metabolic rate $(A D M R)$ was measured at 15 and $20^{\circ} \mathrm{C}$ by the consumption of oxygen, using a closed-system Morrison respirometer (Morrison \& Grodzins ki, 1975). Animals were placed in 20-litre chambers and given nest material, food (grain, carrots, beets) and water ad lib. These measurements were taken on 66 hamsters, more than half of this number in winter and the remainder in summer.

The energetic cost of thermoregulation was established on the basis of the resting metabolic rate $(R M R)$ measured at ambient temperatures from -12 to $+35^{\circ} \mathrm{C}$ (G ór e cki \& W ołek, 1975), using a Kalabukhov-Skvortsov respirometer (Górecki, 1975) and 10-litre respiration chamber. A total of 210 one-hour oxygen consumption measurements were made on 30 hamsters.

In order to determine the calorific equivalent of oxygen, the amounts of oxygen consumed and carbon dioxide breathed out were measured in a paramagnetic open-system respirometer (Spirolyt II). Measurements were taken at 15 and $20^{\circ} \mathrm{C}$ at a flow of $20 \mathrm{l} / \mathrm{hr}$. In this way $R Q$ was established in 14 hamsters.

Changes in the deep body temperature of hamsters caused by changes in ambient temperature were measured in 5 animals, after transmitters had been surgically placed in their body cavities (W e in er \& G $6 \mathrm{recki}$ 1975). Body temperature was thus measured in a continuous way in hamsters exposed to 10 and $20^{\circ} \mathrm{C}$. Three hamsters were exposed to $10^{\circ} \mathrm{C}$ for 13 days and two animals were exposed to $20^{\circ} \mathrm{C}$ for 10 days.

\section{RESULTS}

\subsection{Number of Trappable Hamsters}

In the annual cycle the total number of hamsters was determined by three factors: the natural mortality of hamsters, the appearance of juveniles in the fields and the migration of these animals from one field to another. Such migrations, usually caused by agrotechnical procedures, brought about enormous changes in the number of hamsters. E.g., in the second half of August in 1973 there were 11 hamsters per hectare in a field of lucerne and a week later, after the field had been ploughed, this value decreased to less than 4 hamsters/ha, while in the adjacent 
fields, already sown with wheat and rape, and in the field from which maize had not been gathered yet, their number increased conspicuously. The autumn of 1973 was rather dry, the rainfall being scarcely $19 \mathrm{~mm}$ in the period from mid-August till mid-September; this is why, after the field of lucerne had been ploughed, practically nothing was left to eat and the animals, especially thase which had their burrows in the middle of the field, had to move to neighbouring fields.

The number of burrows falling to one hamster averaged 4.43 for all the years of this study, being lowest in 1974, when the number of hamsters was highest ( 3.75 burrows in the spring and 3.90 in the autumn). The highest numbers of burrows were recorded in 1972, the mean for this year being 5.05 .

In spite of the fact that at each estimation the burrows were counted in an area averaging 2.0 to $7.5 \%$ of the whole field of a given crop, the

Table 1

Number of burrows determined in fields with different crops in the autumn 1974.

\begin{tabular}{|c|c|c|c|c|c|c|}
\hline \multirow[b]{2}{*}{ Field } & \multirow[b]{2}{*}{ Area, ha } & \multirow{2}{*}{$\begin{array}{l}\text { No. of } \\
\text { deter- } \\
\text { mination }\end{array}$} & \multirow{2}{*}{$\begin{array}{c}\text { Examined part } \\
\text { of the } \\
\text { field, } \%\end{array}$} & \multicolumn{3}{|c|}{ Number of burrows } \\
\hline & & & & $\begin{array}{l}\text { Transect } \\
750 \mathrm{~m}^{2} \pm \\
\pm \mathrm{SD}\end{array}$ & C.v., $\%$ & ha \\
\hline Lucerne $^{1}$ & 22 & 10 & 3.4 & $7.30 \pm 3.05$ & 41.7 & $\mathbf{9 7 . 3}$ \\
\hline Wheat 1 & 24 & 8 & 2.5 & $6.75 \pm 1.31$ & 19.4 & 90.0 \\
\hline Vicia faba ${ }^{1}$ & 23 & 6 & 2.0 & $7.33 \pm 3.07$ & 41.8 & 97.7 \\
\hline Maize & 36 & 10 & 2.1 & $4.10 \pm 1.03$ & 25.2 & 47.3 \\
\hline Potatoes & 10 & 5 & 3.8 & $1.40 \pm 1.14$ & 81.4 & 18.7 \\
\hline Pape & 12 & 6 & 3.7 & $1.75 \pm 1.16$ & 66.8 & 23.3 \\
\hline Grasses & 1 & 4 & 30.0 & $3.25 \pm 0.96$ & 29.5 & 43.3 \\
\hline
\end{tabular}

s Stubble

differences between the estimates were rather remarkable - the coefficient of variation often exceeded $40 \%$. In the fields with perennial crops (grasses, clover, lucerne), where the burrows were distributed least uniformly, their number was usually estimated over larger areas. The transects in which the burrows were counted extended obliquely across the whole field, but the number of burrows did not, as a rule, depend upon the distance from its edge. The fields of rape, the peripheries of which more abounded in burrows than the centres, were the only exception. A similar phenomenon was observed in a field of potatoes in 1974. The results of the number estimation made in the autumn of 1974 are given in Table 1.

In each year of study the number of hamsters was distinctly higher in autumn than in spring (Fig. 2). The highest number was observed in the autumn of 1974 when there were about 2150 hamsters in the whole study 
area (128 ha) or $16.8 / \mathrm{ha}$. In the spring 1973 the lowest number of only 3.9 hamsters/ha was noted.

In 1972-1974 the mean annual numbers of hamsters per ha calculated by the method proposed by Petrusewic z \& M c F a d y en (1967) were, 8.4, 7.8 and 9.3 hamsters respectively. These figures do not include the juveniles that appeared in the fields early in the summer, between the censuses. On the basis of the data concerning the number of embryos the number of young animals was estimated and next taken into. account in the calculation of the flow of energy through the whole population (see also Section 3.5.).

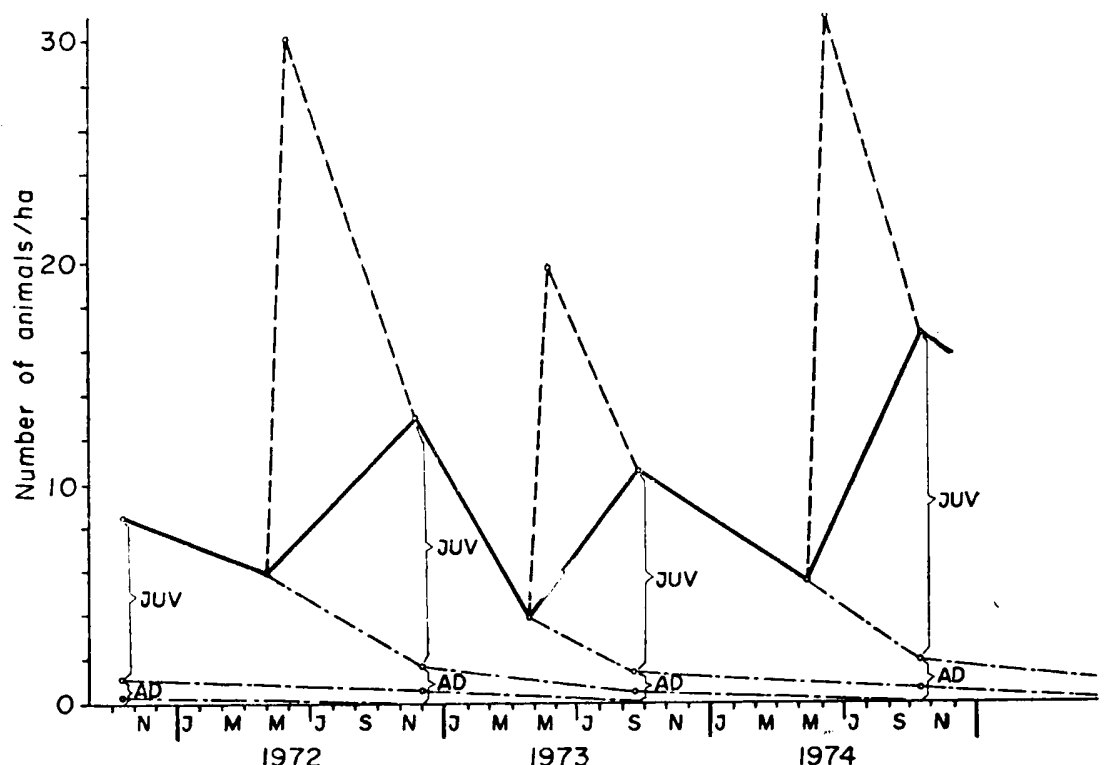

Fig. 2. Dynamics of the number of hamsters.

Solid line-number of animals observed in the field, broken line-number of young determined on the basis of the number of embryos, Juv - young hamsters, Ad - one-year-old and older hamsters.

\subsection{Sex Structure and Reproduction Rate in Hamster Population}

\subsubsection{Sex Structure}

Each year the sex ratio in the population under study was estimated on animals captured in the fields neighbouring upon those in which their number was determined (Fig. 1, Field No. 3). Sex was determined in all the animals captured except juveniles designed for laboratory studies. As the number of animals captured in particular years was too small to permit the determination of the sex structure of the population, the singular captures were summed up. Altogether 109 males and 119 females 
were captured in 1971-1974. Since the difference between these numbers, examined by the chi square test, was not significant at the 0.05 confidence level, it was assumed for further considerations that, as in most other rodent population, the sex ratio is $1: 1$.

\subsubsection{Reproduction - Number of Young}

A total of 25 pregnant females were captured from 20 May to 9 June in two successive years. The average number of embryos per female was 11.4. in 1972 and 9.9 in 1973. The mean number of embryos falling to one pregnant female calculated for these two year was $10.3 \pm 3.4$ (S.D.).

Nestlings were found several times in captures (by flooding the burrows), but their number never exceeded 8 specimens and their mean number from 5 litters captured was $6.8 \pm 1.6$. Unfortunately, the small number of young captured precludes any far-reaching conclusions, especially since their number may have been underestimated because not all of the young left their flooded burrows.

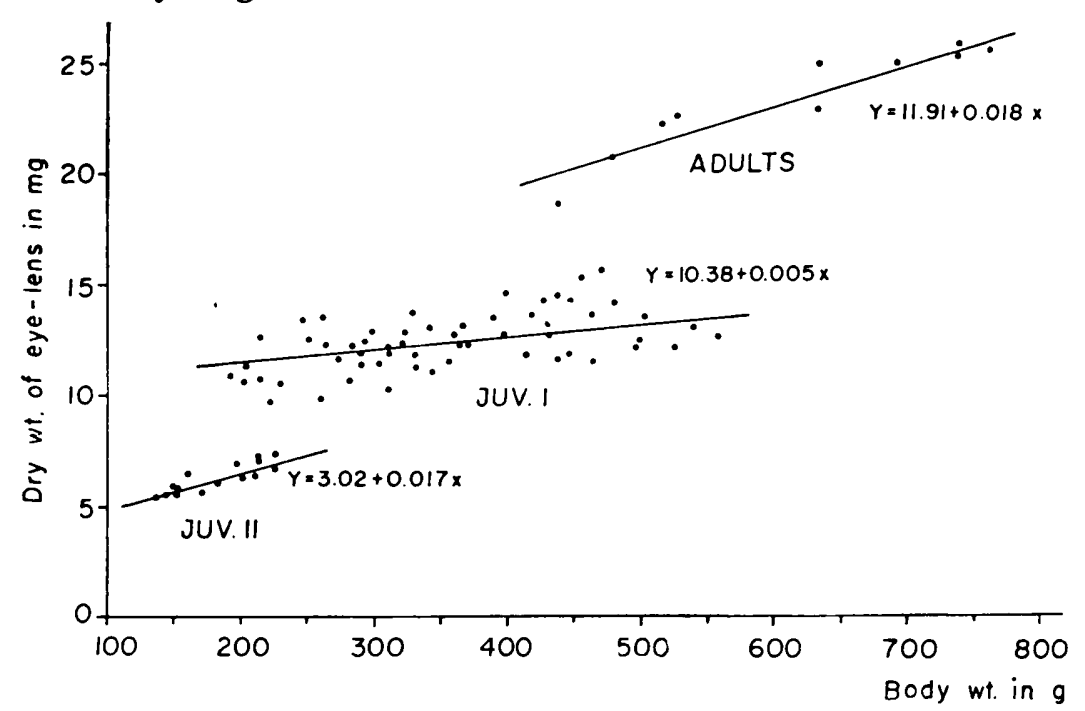

Fig. 3. Relationship between body weight $(X)$ and dry eye-lens weight (Y), differentiating the population into three cohorts.

\subsection{Age Structure of Population}

Forty-eight hamsters were captured in the autumn 1972 and 85 in the autumn 1974. Captures were carried out in control fields (Fig. 1 - Field No. 3), situated in the close vicinity of the fields in which the dynamics of the number were being determined. In the first period (1971-1973), however, only the body weights of animals caught were analysed, but in 1974 the eye lenses were removed from the animal carcasses ( $\mathrm{L}$ ord, 
1959) and on the basis of the weights of their dry matter the animals were divided into three age classes, for in the study period this was the only year in which the hamsters had two litters. The adult hamsters, aged one year or more, formed $11.8 \%$ of the population, the hamsters of the first litter $69.4 \%$ and those of the second liter $18.8 \%$. In spite of differences in body weight between the hamsters (Fig. 3), the dry weights of eye lenses of the hamsters of the first litter lay within narrow limits of $0.0105-0.0140 \mathrm{~g}$ and were sharply demarcated from the weights of lenses

Table 2

Differentiation of body weight and eye-lens weight in three cohorts of autumnal hamster population in 1974.

\begin{tabular}{|c|c|c|c|}
\hline & Adults & $\begin{array}{l}\text { Youngs of the } \\
\text { I litter }\end{array}$ & $\begin{array}{l}\text { Youngs of the } \\
\text { II litter }\end{array}$ \\
\hline $\begin{array}{l}\text { Body wt. } \mathrm{g} \pm \mathrm{SE} \text {; } \\
\text { C.v. \% } \\
\text { Eye-lens wt. } \mathrm{mg} \pm \mathrm{SE} \text {; } \\
\text { C.v. } \% \\
\text { Coefficient of } \\
\text { correlation } \\
\text { Relationship between } \\
\text { b.ody wt. }(X) \text { and lens } \\
\text { wt. (Y) } \\
\text { Significance of } \\
\text { regression coefficient }\end{array}$ & $\begin{array}{rr}618.6 \pm 37.3 ; & 19.3 \\
23.3 \pm 0.74 ; & 10.0 \\
0.941 & \end{array}$ & $\begin{array}{rc}348.1 \pm 12.5 ; & 27.6 \\
12.3 \pm 0.14 ; & 8.9 \\
0.484 & \end{array}$ & $\begin{array}{c}185.1 \pm 7.7 ; 16.6 \\
6.2 \pm 0.16 ; 10.2 \\
0.835 \\
Y=3.02+0.017 X \\
p<0.001\end{array}$ \\
\hline
\end{tabular}

Table 3

Distribution of hamster of the population (number of animals per hectar) according to age.

\begin{tabular}{lccrr}
\hline Date & $\begin{array}{c}\text { Adults, } \\
\text { 1 year }\end{array}$ & $\begin{array}{c}\text { Adults, } \\
\text { 2 years } \\
\text { (or more) }\end{array}$ & Youngs & Total \\
\hline 1971 & 0.80 & 0.34 & 7.36 & 8.5 \\
1972 & 1.21 & 0.52 & 11.17 & 12.9 \\
1973 & 0.99 & 0.43 & 9.18 & 10.6 \\
1974 & 1.39 & 0.59 & 14.82 & 16.8 \\
\hline
\end{tabular}

of the hamsters of the second litter and the adult ones (Fig. 3, Table 2). The differences in lens weight between all the three classes were examined by the $t$ test and appeared to be very significant $(p<0.001)$ in all cases.

The dry eye lenses of the two biggest hamsters ( 860 and $800 \mathrm{~g}$ ), captured in the spring 1974, were also weighed, their weights being, respectively, 0.0278 and $0.0255 \mathrm{~g}$. The molar teeth of these animals were much more heavily worn than in several adult hamsters more than $450 \mathrm{~g}$ in weight and their cranial sutures were ossfied to a distinctly higher 
degree. This points to the fact that the class of adult hamsters contained both one-year-old and older specimens. The class of adult hamsters was divided on the basis of body weight into two subclasses (limit weight $600 \mathrm{~g}$ ), whereas all the young animals were treated together. The results are illustrated in Table 3.

\subsection{Body Weight and Growth of Hamsters}

In 1974 the young hamsters of the second litter were captured at the age of 9 weeks and their weight at that time was about $185 \mathrm{~g}$ (Table 2). The young of the first litter were 27 weeks old at the time of capture and weighed $348.1 \mathrm{~g}$.

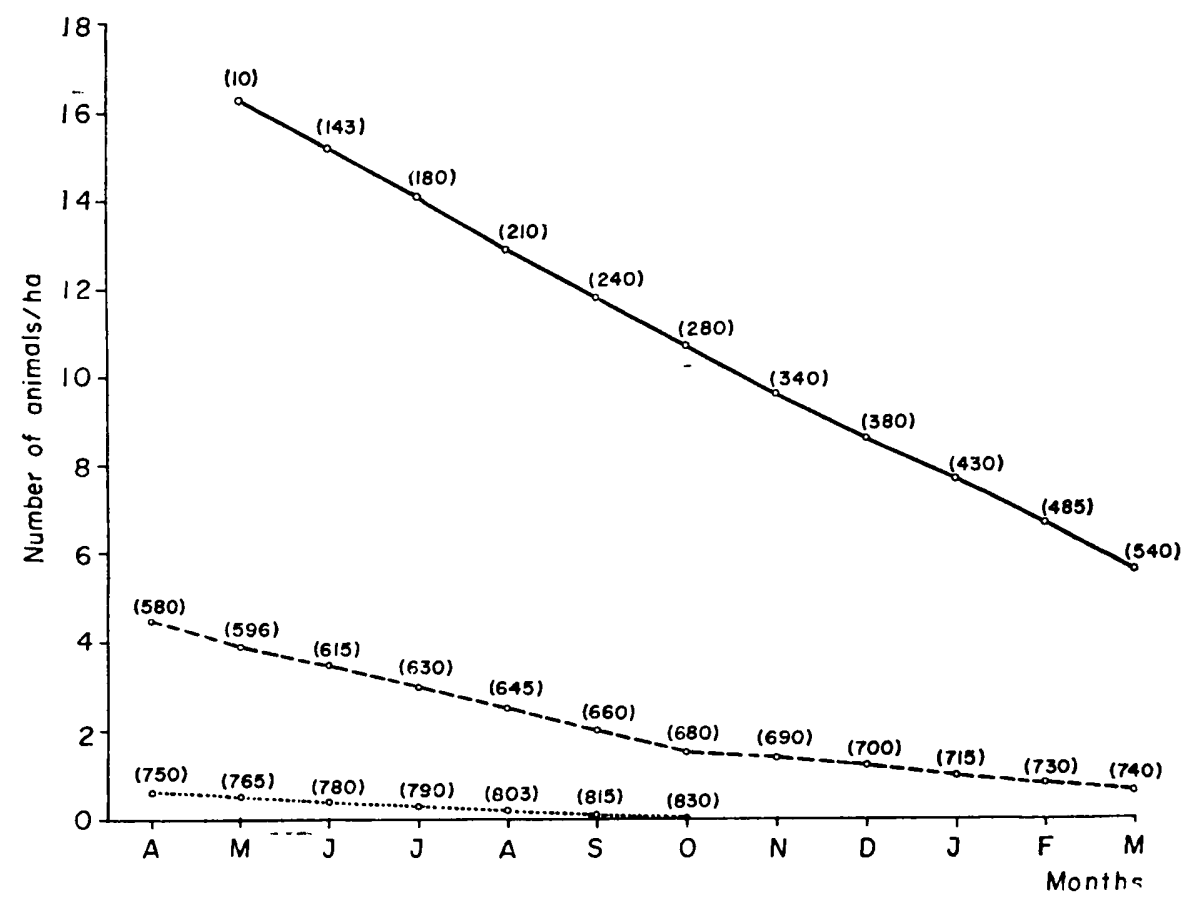

Fig. 4. Density of hamsters and their mean body weights in particular months of the year.

Solid line-young animals up to a year of age, broken line-hamsters up to two years of age, dotted line-2-3-year-old hamsters; in brackets - body weights.

The mean body weight of the "spring « population of hamsters was $422.9 \pm 85.3 \mathrm{~g}(\mathrm{n}=87$ animals). On the other hand, 161 hamsters weighed in autumn were on the average lighter $(319.8 \pm 71.1 \mathrm{~g})$, which naturally was connected with the presence of a large number of juveniles in the sample. The mean body weight was determined on the basis of the age structure of the specimens examined, their density (Fig. 4) and growth 
curve. The mean annual body weight is $371.2 \pm 139.6 \mathrm{~g}$; an average hamster reaches its highest weight in April, whereas in May, when the whole growth of young still proceeds at the cost of females, the mean weight is lowest and amounts to $132.9 \mathrm{~g}$ (Figs. 2 and 4).

Both the foregoing results and the data given by $\mathrm{M} \circ \mathrm{hr}$ et al. (1973) about the period directly following birth made it possible to establish the dependence of body weight upon age in a hamster population over the period of a whole year (Fig. 4).

\subsection{Dynamics of Population Size}

The number of trappable hamsters was determined in the field in spring and in autumn. The peak of abundance occurred, however, in summer months, starting from the end of May, when the juveniles began to leave the nests.

The maximum number of hamsters in the fields (Fig. 2) can easily be calculated from the previously established number of embryos falling to one female (10.3 embryos - Section 3.2.2.) and the number of females in the spring population $(50 \%$ females, of which above $80 \%$ reproductive - French, Stoddart \& Bobek, 1975). This high number soon undergoes a reduction, since the highest mortality rate is observed in rodents just after the young have left the nests (G liw ic z et al., 1968; Petrusewicz, 1970; Petrusewicz \& Hans son, 1975).

Having assumed the mortality at a level of about $42 \%$ in summer and $58.5 \%$ in autumn (cf. Section 3.6.), we were able to calculate the number of hamsters in particular months (Fig. 2 and 4) and their mean annual number. Such a very general mean number for the years $1971-1974$ is 12.3 \pm 5.1 hamsters/ha. The highest density occurs in June, when juveniles appear in fields (19.1/ha - Fig. 2 and 4).

\subsection{Mortality, Survival Table}

Most of the important population parameters, such as the turn-over of number and biomass and the production of a population, demand the knowledge of the survival table. In order to construct it, it is necessary to estimate the probability for hamsters to live till a definite age. The autumn numbers juveniles, one-year-olds, two-year-olds, and older individuals are compared in Table 4, which makes it possible to investigate the fate of particular cohorts of animals. The division into one- and twoyear-old adult specimens was made on the basis of the data obtained in the autumn seasons of 1973 and 1974, when about $30 \%$ of adult hamsters were more than one-year-old. It was taken for granted that virtually all hamsters die by the autumn of the third year. 
The probability of one-year-long survival $\left(p_{1}\right)$, from the first autumn to the second, is

$$
p_{1}=\frac{127+177}{1430+1175}=0.117
$$

whereas the probability of survival throughout the period from the second autumn to the third

$$
p_{2}=\frac{55+76}{127+155}=0.465
$$

The probability of survival calculated in this way permits the construction of a life table with yearly age classes. Since on account of differences in physiology between hamsters in summer and in winter it is indispensable for further considerations to know the changes in the size if particular age classes in these seasons, the intervals had to be reduced to half-year

Table 4

Changes in the numbers of individuals of particular cohorts in successive years. Data based on autumnal estimates.

\begin{tabular}{lrrr}
\hline & \multicolumn{3}{c}{ Number of animals/128 ha } \\
\cline { 2 - 4 } Age classes & 1972 & 1973 & 1974 \\
\hline Youngs & 1430 & 1175 & 1897 \\
Adults - age 1 year & 155 & 127 & 177 \\
Adults - age 2 years & 66 & 55 & 76 \\
Adults - age 3 years & 0 & 0 & 0 \\
\hline
\end{tabular}

ones. For this purpose the decrease in the number of adult hamsters was calculated for the period from the autumn 1973 to the autumn 1974, when the richest material was captured. In the period of active life the reduction of the number of these hamsters was $65.4 \%$ and thus it was higher than in the winter, when $46.2 \%$ of the hamsters perished. The probability of survival of the half-year period from spring to autumn $\left(p_{a}\right)$ can therefore be computed from the equation

$$
p_{a}=1-0.654=0.346
$$

and from autumn to spring analogously

$$
p_{w}=1-0.462=0.538
$$

Probabilities $p_{a}$ and $p_{w}$ were calculated for an average hamster above half a year of age. The chances of hamsters to survive the period of active life and that of winter undoubtedly change with age. However, it was assumed that their mutual relation remains constant throughout their life and thus

$$
p_{a}=0.643 p_{w}
$$

for all age classes. For hamsters in the first year of life $p_{1}=p_{w} \times p_{a}=$ 0.117 . Substituting $p_{a}$ from formula (5) in this equation, we obtained 
the probability of survival of the first winter, which was 0.462 , and the following summer, 0.275. Analogous reasoning was used for older hamsters and their probability of survival was calculated to be 0.849 for winter and 0.548 for summer. As can be seen, the chance to survive winter is better in the case of all hamsters.

Now, only the probability of survival of the period from birth to the first autumn $\left(p_{0}\right)$ is needed for the construction of the survival table of hamsters. On account of the similarity of the mean numbers in successive years, it was assumed that the mean number of hamsters for many years is constant or that the measure of net reproduction, $R_{0}$, equals unity. This measure is defined by the formula

$$
R_{0}=\Sigma_{x} l_{x} f_{x}
$$

where $l$ is the probability of survival till the age of $x$ and $f$ the number of female offspring falling to a female at the age of $x$ (M A A thur \& Connell, 1966).

\section{Table 5}

Life table of hamster population.

$x$-age class in years, $l_{x}$ - the number surviving at the beginning of age class $x, d_{x}$ - the number dying during the age interval $x, q_{x}-$ the rate of mortality, $e_{x}$ - the expectation of life remaining for individuals of age $x, f_{x}$ - number of female offspring born to a female in age $x$.

\begin{tabular}{crrrrl}
\hline$x$ & $l_{x}$ & $d_{x}$ & $q_{x}$ & $e_{x}$ & $f_{x}$ \\
\hline $0.0-0.5$ & 1000 & 630 & 63.0 & 0.56 & 0 \\
$0.5-1.0$ & 370 & 212 & 57.3 & 0.60 & 0 \\
$1.0-1.5$ & 158 & 115 & 72.8 & 0.56 & 5.15 \\
$1.5-2.0$ & 43 & 6 & 13.9 & 0.91 & 0 \\
$2.0-2.5$ & 37 & 17 & 45.9 & 0.52 & 5.15 \\
$2.5-3.0$ & 20 & 20 & 100.0 & 0.25 & 0 \\
$3.0-3.5$ & 0 & 0 & - & 0.00 & 0 \\
\hline
\end{tabular}

In determining the value of $f_{x}$, it was assumed that the female produces its first litter in the spring of the year following the year of its birth or at the age of $1.0-1.5$ years. As the second litter was observed only once during the five-year study of hamsters and even then it was much less numerous than the first litter, it was assumed for calculation that the female produces young only once a year, which situation was rather typical in the study region. It was also assumed that the sex ratio of the offspring is $1: 1$. According to the empirical data 10.3 embryos fall to one female or $f_{x}=5.15$ (Table 5).

Successive values of $l_{x}$ were substituted in formula (6) (Table 5), and $p_{0}$ was calculated to be 0.370 . This value of $p_{0}$ makes it possible to calculate the probability of survival till the beginning of a given age interval $(l)$, which in turn permits the computation of the mortality in the given 
age class $\left(d_{x}\right)$, the mean life expectancy $(\bar{t})$, and the turnover of the biomass $(\Theta)$ of these individuals. The mean life expectancy of hamsters was 0.564 year, i.e. nearly seven months, and the turnover of number 1.77.

\subsection{Production of Population}

In the study period the mean number of hamsters in the whole area of 128 ha was 660, half of which or 330 were females. If the number of females reproducing in spring is diminished by substracting from it the second litter from the previous autumn, which perhaps did not take part in reproduction then and besides does not often occur at all, about $88 \%$ or 291 females gave birth. The pregnant females of the whole study area therefore produced total of 2997.3 embryos. Even if the resorption of embryos was very high (up to $10 \%$ - P elián, 1967, 1970), still

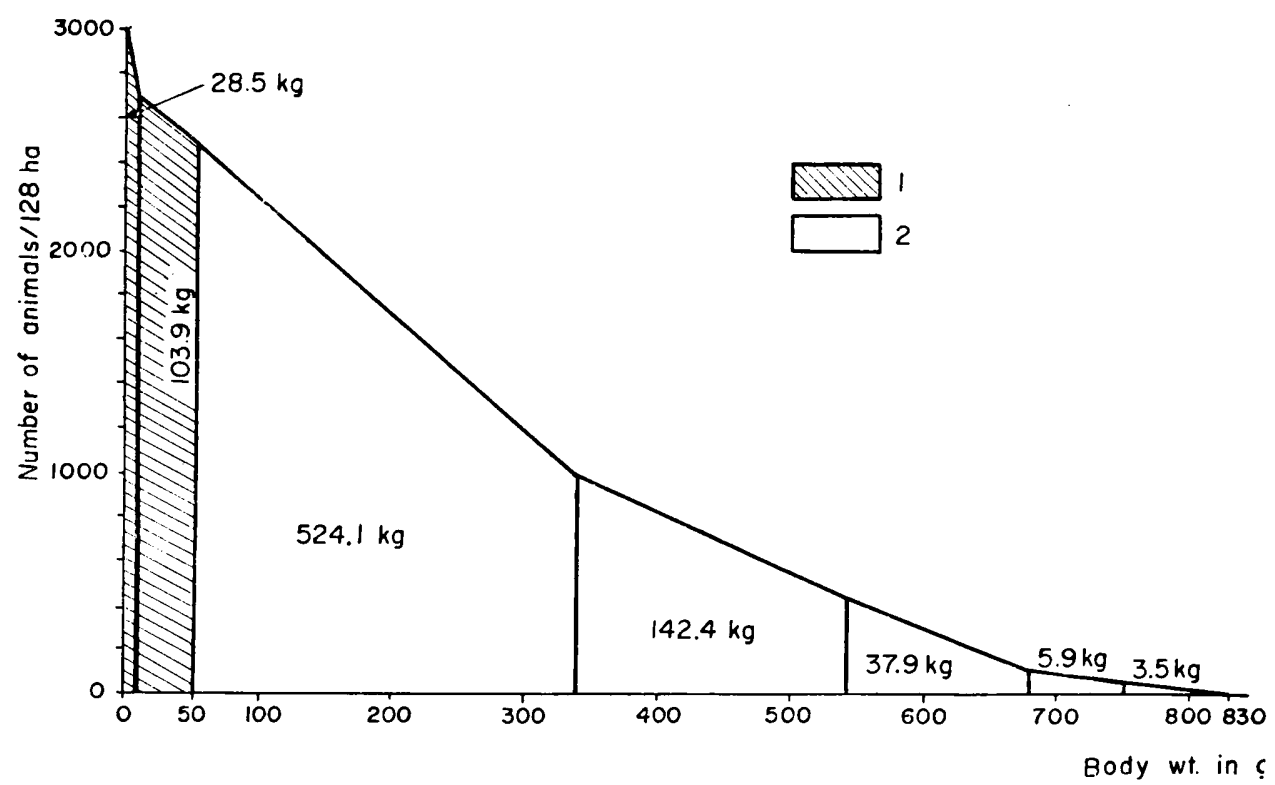

Fig. 5. Production of hamster population calculated on the basis of life tables. 1 -reproduction production $\left(P_{r}\right), 2$-growth production $\left(P_{\mathrm{g}}\right)$. All values in $\mathrm{kg} / 128 \mathrm{ha} \times \mathrm{yr}$.

2697.6 young hamsters were born, each of them weighing about $10 \mathrm{~g}$ (Mohr et al., 1973; Vohralik, 1975) (Fig. 5). Consequently, the production of embryos $P_{E}=[(2997.3+2697.6): 2] \times 10 \mathrm{~g}=28474.5 \mathrm{~g}$. At the $63 \%$ mortality, characteristic of that hime (Table 5), there were 998.1 half-year-old hamsters, approximating $340 \mathrm{~g}$ in body weight each (autumn data for the first litter). Thus the production at that time was $609.8 \mathrm{~kg}$.

This value of production includes the production at the cost of the female (lactation $-P_{L}$ ), which can be determined, if we know the body weight of the young ones that begin to feed by themselves. This weight 
is however very hard to establish in a hamster population, because young animals begin to take supplementary food as early as the eighth day of life (Kow a ls ki. 1964), gradually replacing mother's milk with vegetable food. The body weight of hamsters that begin to feed by themselves was arbitrarily estimated at about $50 \mathrm{~g}$. About 2500 juveniles left the nests (Fig. 5) and thus the production until this age was $103.9 \mathrm{~kg}$. The total production due to reproduction $\left(P_{R}\right)$ was $132.4 \mathrm{~kg}$.

Since $42.7 \%$ of the population survived from the age of six months to the age of a year (Table 5) and the weight of a one-year-old hamster was about $540 \mathrm{~g}$ (data from autumn captures), the production in this half-year period was $142.4 \mathrm{~kg}$. The production of hamsters in the next half-year (1.0-1.5 years old) was $37.9 \mathrm{~kg}$, the calculation being based on the body weight, $680 \mathrm{~g}$, of 7 hamsters captured in the autumn; the age of these animals was determined on the basis of the weight of their eye lenses and the wear of teeth, estimated by comparing them with the teeth of juveniles weighing about $300 \mathrm{~g}$. The weight of $750 \mathrm{~g}$ was assumed for the next class, because this value was attained by the oldest specimens in which the age was determined. Here the production was $5.9 \mathrm{~kg}$. Lastly, the weight of the two biggest hamsters captured during this study was assumed for the remaining specimens (Fig. 5). It was $830 \mathrm{~g}$ and then the production was $3.5 \mathrm{~kg}$.

The production over the whole life of hamsters in the whole study area of 128 ha reached $828.1 \mathrm{~kg}$ or about $6.5 \mathrm{~kg} / \mathrm{ha}$. The production due to reproduction $\left(P_{R}\right)$ was $1.03 \mathrm{~kg} / \mathrm{ha}$ and that due to growth $\left(P_{G}\right) 5.43 \mathrm{~kg} / \mathrm{ha}$. In most rodent populations the production due to reproduction form at least a half of the total production, whereas in hamsters it constitutes hardly $16 \%$ (P e tru se wic z \& $\mathrm{H}$ ans on, 1975).

The turnover of biomass $\left(\Theta_{B}\right)$ can be calculated retrogressively from the foregoing data and the number of individuals (Petrusewicz, 1966, 1967; P etruse wic z \& M c F a d ye n, 1970):

$$
\Theta_{B}=P_{N}: B
$$

where $P_{N}$ is the net production and $\bar{B}$ the mean biomass $\left(N_{b} \times B_{b}\right)$.

The mean number (including young arimals) in three consecutive years, 1972-1974, was 12.4 hamsters/ha and the mean annual body weight in the population was $371.3 \mathrm{~g}$. The substitution of these values gives the turnover of biomass $\left(\Theta_{B}\right)$ equal to 1.40 . This value is therefore lower than the turnover of numbers $\left(\Theta_{N}\right)$ calculated previously. Thus the phenomenon of slight inferiority of the turnover of biomass to that of numbers, observed in rodent populations, occurred also here (Petrusewicz, 1966; Petrusewicz, Andrzejewski, Bujalska \& Gliwicz, 1968; B o b e k, 1973).

An identical turnover of biomass was computed for a population of 
Proechimys, a rodent resembling the common hamster in size and living in the tropical rain forests of Panama (G liw i c $z, 1973$ ). This turnover is however distinctly lower than, e.g. the turnover in the population of Clethrionomys glareolus (P e truse wic z et al. 1968).

\subsection{Daily Activity Rhythm and Sums}

The method used to determine the daily activity of hamsters permits measurements in natural environment without disturbing the natural activity pattern of these animals. The results from summer (from May to July) differ somewhat from the autumn one (August-October). In

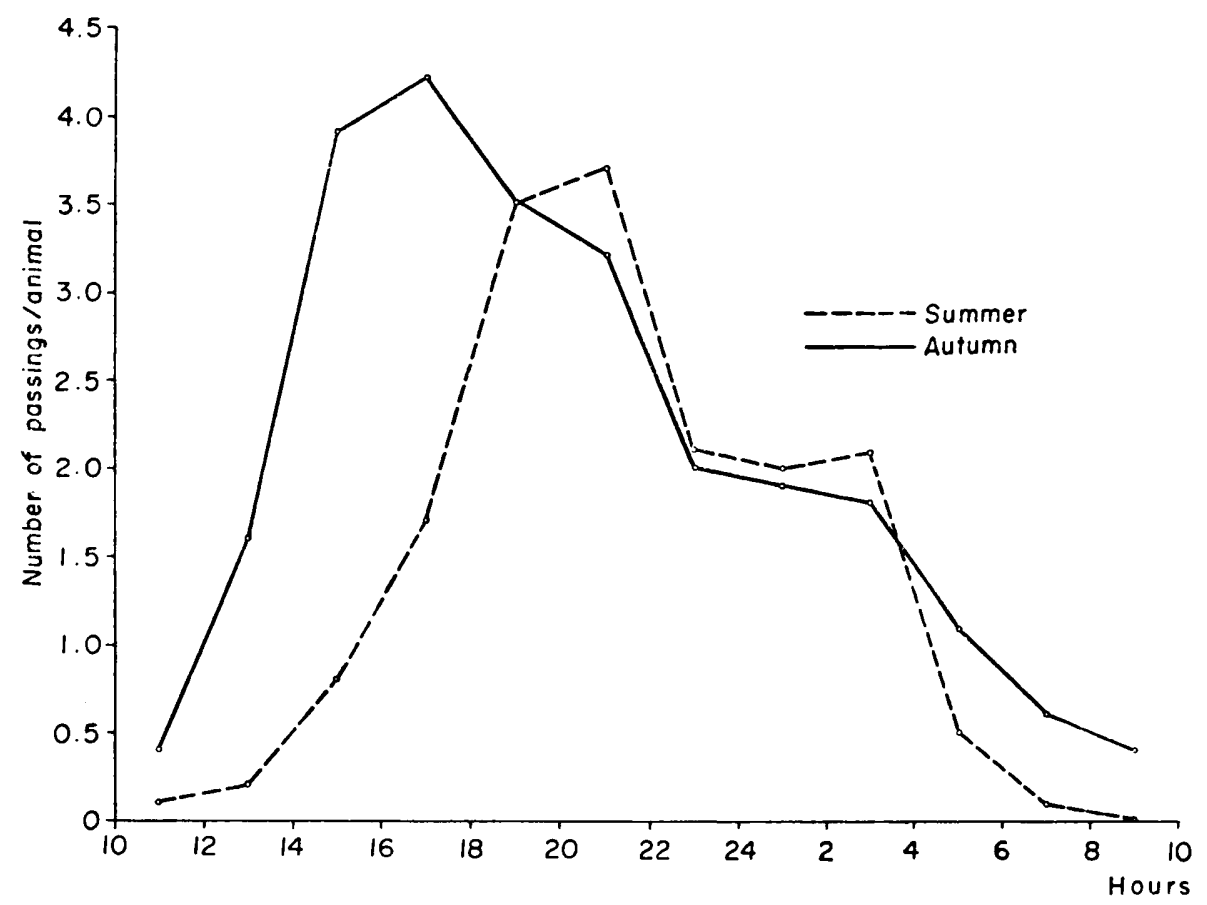

Fig. 6. Rhythm of daily activity of hamsters measured by the numbers of goings out of and comings into the burrow in summer and autumn.

summer the number of goings out of the burrow calculated for one hamster was 8.4. The activity rhythm (Fig. 6) had as a rule two peaks, the main peak about 8 p.m. and the lower one in the small hours of the day, from 0 to 2 a.m. In autumn the number of goings out of the burrow per hamster increased considerably, up to 12.3/day. The activity rhythm still had two peaks, but the main peak was shifted to earlier hours (4 to 6 p.m.) and was much wider at that (Fig. 6).

It was also found in sporadic observations made over the whole period of this study that the time of one stay of an animal out of the burrow 
was shorter in summer than in autumn. If in summer such a stay did not exceed 20-25 minutes, in autumn a stay often exceeded $30-35$ minutes. Often some individuals were observed in the fields (e.g. those of maize) as far as several hundred metres from their burrows, and it was just in such cases that the time of their stay out of the burrow exceeded 35 minutes.

Since in summer one hamster left its burrow on the average 8.4 times. a day, the time of its stay on the ground was about $3.5 \mathrm{hrs}$ per day, compared with $6-7$ hrs per day in autumn.

\subsection{Average Daily Metabolic Rate (ADMR) of Hamsters and Their}

\section{Body Temperature}

$A D M R$ of hamsters was studied at two ambient temperatures, 15 and $20^{\circ} \mathrm{C}$. The body weights of animals examined differed rather much and ranged from 234 to $629 \mathrm{~g}$ at $15^{\circ} \mathrm{C}$ and from 187 to $629 \mathrm{~g}$ at $20^{\circ} \mathrm{C}$, which permitted the calculation of the relationship between metabolism and body weight (Fig. 7). The regression equations and coefficients of cor-

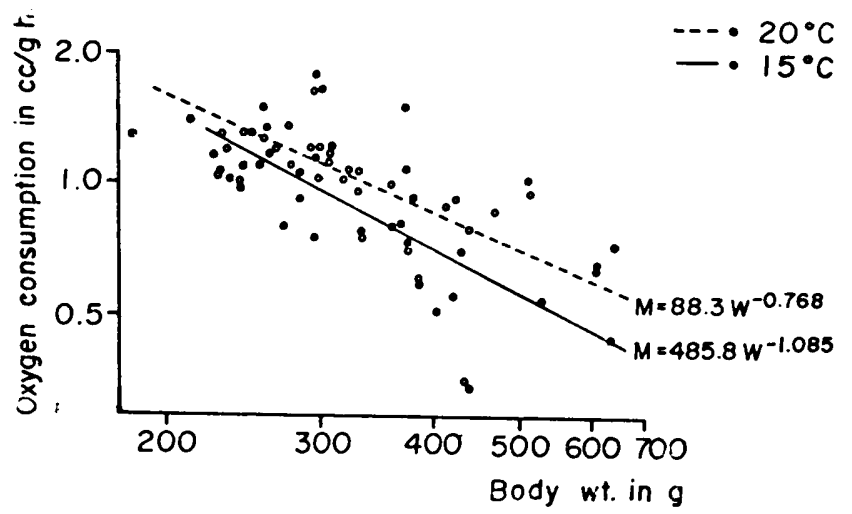

Fig. 7. Relationship between the mean daily metabolic rate of hamsters (M) at 15 and $20^{\circ} \mathrm{C}$ and their body weight. Double-log scale.

relation and regression (Table 6) indicate that the dependence of the metabolic rate upon the body weight was very highly significant.

The daily rhythm of metabolic rate (Fig. 8) showed an extreme coincidence at the time of activity of these animals at both ambient temperatures applied. The peak of this activity occurred at night, between 10 and 12 p.m. There was however a slight difference at time of their minimum activity and then the metabolism measured at $15^{\circ} \mathrm{C}$ was somewhat lower than at $20^{\circ} \mathrm{C}$ (Fig. 8). This result influenced the total result so that $A D M R$ at $15^{\circ} \mathrm{C}$ was lower than at $20^{\circ} \mathrm{C}$ by about $15 \%$. At both temperatures the maximum metabolic rate was on 
the average 2.11 times as high as the minimum one, which was $0.69 \mathrm{cc} \mathrm{O}_{2} / \mathrm{g} \mathrm{hr}$. The consumption of oxygen in night hours was 1.36 times as high as in the day-time.

Table 6

Average daily metabolic rate $(A D M R)$ of hamsters measured at ampient temperatures 15 and $20^{\circ} \mathrm{C}$ and its dependence upon body weight.

\begin{tabular}{llll}
\hline$A D M R\left(\mathrm{cc} \mathrm{O}_{2} / \mathrm{g}\right.$ & & & \\
$\mathrm{hr} \pm \mathrm{SE})$ & $1.00 \pm 0.07\left(\right.$ at $\left.15^{\circ} \mathrm{C}\right)$ & $1.08 \pm 0.05$ (at $\left.20^{\circ} \mathrm{C}\right)$ & 1.04 (average) \\
$\mathrm{Max} D M R$ & 1.46 & 1.44 & 1.45 \\
Max/Min $D M R$ ratio & 2.3 & 1.9 & 2.1 \\
Night/Day ratio & 1.51 & 1.26 & 1.36 \\
Body weight, g $\pm \mathrm{SE}$ & $334.0 \pm 19.6$ & $347.1 \pm 16.9$ & 341.7 \\
$A D M R(M)$ and body & & & \\
wt. $(W)$ correlation & & -0.602 & -0.642 \\
coefficient & -0.708 & $0.01<p<0.02$ & \\
& $0.02<p<0.05$ & $M=88.3 W-0.768$ & $M=162.9 W-0.883$ \\
Regression equation & $M=485.8 W-1.085$ & $p<0.001$ & $p<0.001$ \\
\hline
\end{tabular}

Most $A D M R$ measurements were made in the winter (on animals captured late in the autumn), at the time when hamsters hibernate under natural conditions. It appeared however that the results obtained in the winter did not differ significantly $(p<0.05)$ from the summer results.

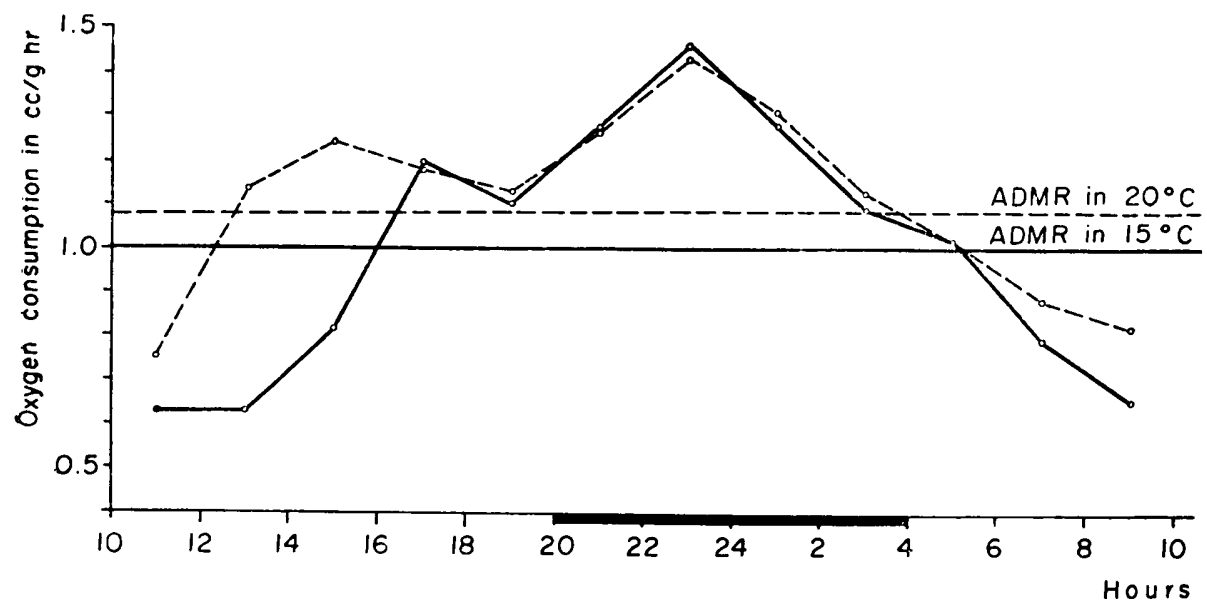

Fig. 8. Daily metabolic rhythm of hamsters at two ambient temperatures. The thickened line of the $x$-axis represents night-time.

The differences in body weight between two groups were at the borderlevel of statistical significance $(p=0.05)$. Consequently, the resuits obtained both in the summer and in the winter could be analysed together (Table 6).

The metabolic rates of hamsters measured at 15 and $20^{\circ} \mathrm{C}$ did not differ significantly $(p<0.02)$, neither did the body weights of hamsters 
differ betwen the two groups $(p<0.01)$. Thus, the metabolic rates at 15 and $20^{\circ} \mathrm{C}$ could be pooled together to calculate the common dependence of $A D M R$ upon body weight for both ambient temperatures: $A D M R$ (cc $\mathrm{O}_{2} / \mathrm{g}$ day) $=7.05 \mathrm{~W}^{-0.883}$. This equation was used later as the basis for construction of the daily energy budgets of hamsters.

The measurements of $A D M R$ were carried out for several days (above 75 hours) at both ambient temperatures. They were made for 10 hamsters at $20^{\circ} \mathrm{C}$ and for 6 at $15^{\circ} \mathrm{C}$. The mean body weight of the hamsters used at $20^{\circ} \mathrm{C}$ was $425 \mathrm{~g}$ and at $15^{\circ} \mathrm{C} 408 \mathrm{~g}$. The oxygen consumption in the first day was rather high and amounted to $1.11 \mathrm{cc} / \mathrm{g} \mathrm{hr}$ at $20^{\circ} \mathrm{C}$ and 0.94 at $15^{\circ} \mathrm{C}$ (Fig. 9). It the following days $A D M R$ decreased distinctly and the differences between consecutive days were not significant ( $p$ always below 0.05). At $15^{\circ} \mathrm{C}$ it was 0.69 and at $20^{\circ} \mathrm{C} 0.87 \mathrm{cc} / \mathrm{g} \mathrm{hr}$, retaining a similar daily rhythm. The results seemed to indicate a fall in the body

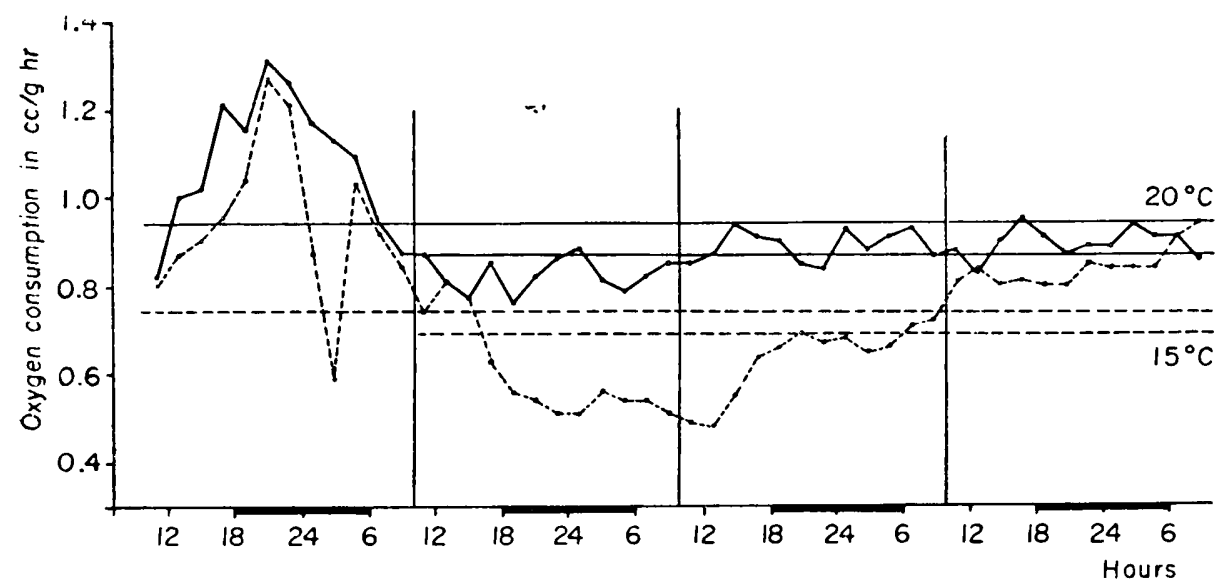

Fig. 9. Rhythm of $A D M R$ of hamsters measured at 15 and $20^{\circ} \mathrm{C}$ during an uninterrupted four-day experiment.

Thickened line of $x$-axis - night-time, longer, solid and broken, straight lines $A D M R$ for the whole period of measurements, shorter lines - $A D M R$ for three days.

temperature of hamsters during these measurements, which however was not confirmed by the continuous telemetric measurements of deep body temperature on animals exposed to 10 and $20^{\circ} \mathrm{C}$. These measurements were made on 5 hamsters over a period of $4-7$ days (Fig. 10).

In the course of the days of exposure the body temperature of the hamsters did not change in an essential manner; as indicated by the range of variation, it did not show a tendency towards either direction of changes. Both at 10 and at $20^{\circ} \mathrm{C}$ the body temperatures of hamsters were very similar and lay within narrow limits of $37-38^{\circ} \mathrm{C}$ (Fig. 10). The rhythm of changes at both ambient temperatures was similar; the 
highest values were noted in the afternoon, but the differences were small and did not exceed $0.5^{\circ} \mathrm{C}$. The very interesting problem of relationship between metabolism and body temperature in hamsters seems to need further studies.

\subsection{Chemical Thermoregulation}

The production of heat for the maintenance of stable body temperature was determined by the consumption of oxygen within a range of ambient temperatures from -12 to $+35^{\circ}$ (Górecki \& Wołek, 1975).

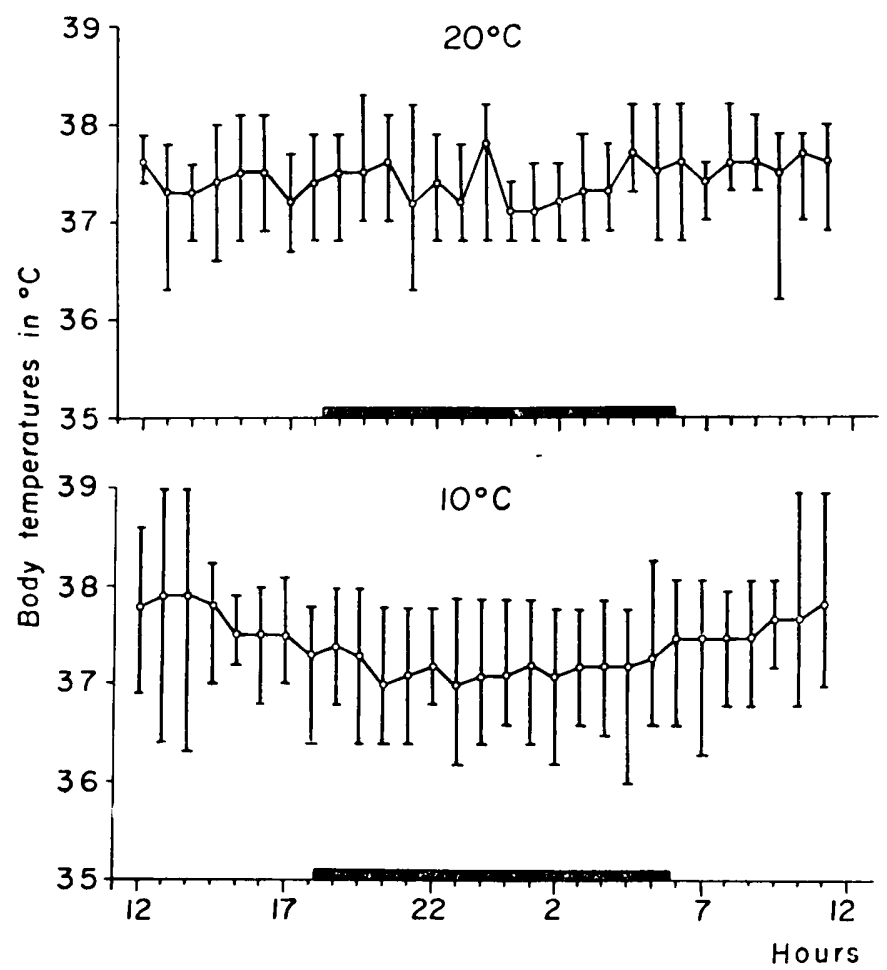

Fig. 10. Daily fluctuations of deep body temperature of hamsters exposed to 10 and $20^{\circ} \mathrm{C}$. Mean values and ranges of variation are given.

The dependence of metabolism $(M)$ upon ambient temperature $(T)$ at physiologically low temperatures is defined by the equation

$$
M\left(\mathrm{cc} \mathrm{O}_{2} / \mathrm{g} \mathrm{hr}\right)=1.97-0.07 \mathrm{~T}
$$

The intensity of heat production for thermoregulation is $5.33 \% /{ }^{\circ} \mathrm{C}$ within a range of $T_{a}$ from -12 to $+27.5^{\circ} \mathrm{C}$ and $4.44 \% /{ }^{\circ} \mathrm{C}$ within a range from 20 to $0^{\circ} \mathrm{C}$ and then it is very high as for an animal of so great a body weight. 


\subsection{Respiratory Quotient (RQ)}

In order to determine the calorific equivalent of oxygen the amounts of $\mathrm{O}_{2}$ consumed and $\mathrm{CO}_{2}$ produced at that time were measured in a paramagnetic respirometer. Before measurement the animals were given a mixed diet, the same as was applied during measurement of $A D M R$ and $R M R$.

$R Q$ measured at $20^{\circ} \mathrm{C}$ in 9 hamsters averaged $0.72 \pm$ (SE) 0.02 and at $15^{\circ} \mathrm{C}$ in 5 hamsters it was nearly the same $(0.71 \pm 0.03)$. As these values do not differ significantly both results were treated together. The calorific equivalent of oxygen was to be assumed $4.7 \mathrm{kcal} / 1 \mathrm{O}_{2}$ (acc. to $\mathrm{K} l$ e i b e r, 1961).

\subsection{Food Storage}

In the autumn of 1973 and 197416 burrows were excavated to investigate the winter food supplies of hamsters. Although the excavated burrows were inhabited by hamsters (in two cases the animal was caught in the burrow) and the course of the passages of the burrows had been marked with coloured water prior to excavation, we failed to dig out the stored provisions. In two burrows we found 0.8 and $1.4 \mathrm{~kg}$ of corn and maize grain, but they were shallow burrows without chambers and ramifications and were used as temporary hiding places and not as main residential ones.

Because of the failure in determination of the magnitude of supplies a direct attempt was made to find them by computing how much food hamsters bring to their burrows. Maize grain from the cheekpouches of two hamsters (body weight about $350 \mathrm{~g}$ ), captured while they were carrying food, was weighed. A hamster appeared to carry $9.5 \mathrm{~g}$ of dry matter of grain at a time. Maize ripened ununiformly in the field so that the hamsters were able to gather ripe seeds and carry them to the burrows for 3 to 5 weeks. On the assumption that each departure from the burrow was combined with gathering food, a relatively small hamster, leaving the burrow 12.3 times a day (see Section 3.5.), was ables to store about $117 \mathrm{~g}$ of grain daily. This makes about $2.9 \mathrm{~kg}$ of grain of maize only during the period of $3-4$ weeks.

As can be seen from field observations, hamsters store their supplies for about 90 days, from August to October. In this period a relatively small hamster can store a maximum of about $10.5 \mathrm{~kg}$ of dry matter of grain. Within the same time a larger animal can probably store larger amounts of food. However, the amount exceding $15-20 \mathrm{~kg}$, given by some authors (e.g. W a lke r, 1964), seem rather doubtful. 


\subsection{Bioclimate}

In addition to the many-year data, the air temperatures in the hours of maximum activity of hamsters were calculated for the four-year period of study (1971-1974) on the basis of the records of thermographs so that they might be used in computing the daily energy budget of the hamster population under study. The highest activity of these animals fell on the average between 3 and 11 p.m. in the period of summer and autumn (see Section 3.8.). These temperatures were next used to calculate the energy cost of the out-of-nest activity of hamsters. As can be seen, the temperatures at the time of maximum activity differ rather considerably from the mean daily air temperatures at a height of $2 \mathrm{~m}$ (Table 7). The last column of the table presents the temperatures at

Table 7

Some climatic parameters of study area.

\begin{tabular}{|c|c|c|c|c|c|c|c|}
\hline \multirow[b]{2}{*}{ Months } & \multicolumn{2}{|c|}{$1949-1971$} & \multicolumn{5}{|c|}{ Temperatures: } \\
\hline & $\begin{array}{l}\text { Air tempt., } \\
{ }^{\circ} \mathrm{C}(2 \mathrm{~m})\end{array}$ & $\begin{array}{l}\text { Rainfall, } \\
\text { mm }\end{array}$ & $\begin{array}{l}\text { Ground } \\
\text { surface }{ }^{1}\end{array}$ & $\begin{array}{l}\text { Depth } \\
50 \mathrm{~cm}^{1}\end{array}$ & $\begin{array}{l}\text { During } m \\
\text { activit } \\
\text { of hams }\end{array}$ & $\begin{array}{l}\text { nax. } \\
\text { y } \\
\text { ters }\end{array}$ & $\begin{array}{l}\text { Depth } \\
160 \mathrm{~cm}^{2}\end{array}$ \\
\hline January & -3.7 & 26.0 & - & 0.3 & - & & 3.4 \\
\hline February & -2.7 & 24.2 & -1.9 & 0.3 & - & & 3.0 \\
\hline March & 1.3 & 26.8 & -3.6 & 2.0 & - & & 2.6 \\
\hline April & 8.4 & 32.0 & 0.9 & 7.0 & - & & 2.3 \\
\hline May & 13.4 & 57.3 & 5.6 & 11.9 & $8.9)$ & & - \\
\hline June & 17.1 & 75.2 & 8.7 & 15.7 & 14.4 & & $3-$ \\
\hline July & 18.4 & 95.3 & 11.5 & 18.0 & 17.2 & $13.9^{\circ}$ & - \\
\hline August & 17.8 & 66.1 & 9.2 & 18.3 & $15.2)$ & & - \\
\hline September & 13.8 & 46.0 & 5.5 & 15.0 & 11.9 & & - \\
\hline October & 8.7 & 31.8 & 0.1 & 9.5 & 5.4 & $7.2^{3}$ & - \\
\hline November & 3.7 & 40.2 & -2.9 & 4.4 & $3.9)$ & & 6.0 \\
\hline December & -0.3 & 36.1 & -7.0 & 0.4 & - & & 4.4 \\
\hline Annual mean/sum & 8.0 & 557.0 & 5.2 & & & & \\
\hline
\end{tabular}

1 1972-1974; ${ }^{2}$ Accounted from Molg a, 1958; with snow cover; 8 Average.

a depth of $1.6 \mathrm{~m}$ (converted acc. to $\mathrm{Molg}$ a, 1958), taking into account the effect of snow cover (Formozow, 1946), for hamsters' nest chambers are usually situated at this depth in winter. On the basis of empirical data obtained by Molga (l.c.) the temperature at a depth of $1.6 \mathrm{~m}$ in the soil, with or without snow cover was raised by $40-80 \%$ in successive months of winter. These temperatures were used to calculate the costs of the activity of hamsters during the pauses in hibernation.

\section{DISCUSSION}

\subsection{Dynamics of Number}

The determination of the actual number of hamsters was possible only after making several assumptions. It was thus assumed that only one hamster as a rule inhabits a burrow, further that about $20 \%$ of 
females take part in reproduction and that a female gives birth to only one litter yearly. Lastly, several demographic parameters concerning the population under study were also assumed. Then, it was necessary to compare the views of different authors on these assumptions and, if possible, to find if they were relevant to the population being examined.

There is an extensive paper on the demographic parameters of various mammalian species published by $\mathrm{French}$, Stoddart \& Bobek (1975), but none of the values given in it refers to hamsters. The mean values specified for the whole group Cricetinae may however be compared with the results obtained and assumptions made in the present paper. Naturally, such a comparison can be only very general, since these mean values for the whole family Cricetidae were calculated from rather considerably varying parameters for concrete species, obtained under very various climatic conditions.

All the estimates of the number were based on the assumption that except for the breeding season hamsters live singly in their burrows. In literature only one author ( $\mathrm{t}$ rog a n ova, 1954) states the occurrence of several hamsters in one burrow, which however has not been confirmed by any other writer. Petzsch (1952) and Popov (1960) never found the presence of more than one hamster in a burrow. S a mos (1975) writes even that always when two hamsters had been introduced into an artificial burrow, one of them was soon bitten to death. These facts were corroborated by the author's own observations. In the period of 5 years 450 hamsters were captured by the flooding method and always only one hamster left one burrow. Naturally, females with young were exceptions and then only during a short period of nursing. In the light of the foregoing data it seems that the assumption, which might have been the source of some errors, is congruous with the behaviour pattern of hamsters.

The density calculated in the present paper, as the most general mean from several years, was about 12 hamsters/ha and thus very similar to that given by French, Stoddart \& Bobek (1975), who, having juxtaposed the data obtained by different autors, demonstrated that in the Cricetinae the density fluctuates between 10 and 15 individuals/ha, according to season. However, there were distinct differences in some demographic parameters. The life expectancy calculated in the present study was 6.7 months, whereas its interspecific mean for the Cricetinae was 3.6 months. Similarly, the number of embryos, which can be calculated from the tables given by those authors, is clearly lower than that obtained for the Cricetus population (respecively, 5.8 and 10.3 embryos per female). In the hamster population the number of females taking part in reproduction, though only an estimate, seems to be higher 
than its interspecific mean. The greatest difference is however that in the number of litters per year. In the population under study hamsters had the second litter only once in five years, whereas the abovementioned authors write that the mean numbers of litters exceeded three per year for all the cricetine species that they had data for. A sinilar number, this time exclusively for hamsters, is given by $\mathrm{Kow}$ a l $\mathrm{k \textrm {k }}$ (1964), and W a l ker (1964) writes about two litters yearly. The general interspecific mean value is naturally influenced by the higher numbers of litters in small members of this family.

Concluding this comparison, I venture the supposition that the picture of the dynamics of the number of hamsters presented in this paper is fairly true and does not deviate much from the changes which occur in the field.

\subsection{Energetics of Hamster Population}

\subsubsection{Hibernation and Energy Sources in Winter}

Under thermal conditions prevailing in the study area the hibernation season usually lasted for about 5 months or, if the outset of winter was early, for $\mathbf{5 . 5}$ months. The hamsters sank into the winter sleep from the end of October to mid-November and usually started their active life in mid-April. In the winter hamsters have at their disposal two sou:ces of energy, fat substances deposited in their body and food supplies stored in the autumn.

$\mathrm{K}$ a y s e $\mathrm{r}(1961,1971)$ observed several hamsters over the five-month period of hibernation at $7^{\circ} \mathrm{C}$ under laboratory conditions. In these aninals he examined the length of the period of uninterrupted sleep, charges in body weight, and fat content. In October and November the aninals hibernated contimuously 63 and $78 \%$ of the time and during these months their body weight decreased by $13 \%$. In December and Jantary the hamsters "slept « on the average half the time, their body we.ght increased somewhat at first and then dropped by nearly $17 \%$. The maximum decrease in the body weight of hamsters averaged $13 \%$. During the last two months the percentage of "sleep" diminished on the average to $30 \%$ and the weight of hamsters increased slowly to $r$ tach the autumnal level.

These observation show clearly that in the first part of the winter hamsters wake up for a very short time and avail themselves chifly of substances deposited in their body and relatively little of suprlies stored in the burrows. In the second half of the winter, when the entrgy stored in their body has already run out, hamsters begin to complement it by eating intensely, as indicated by the shortened "sleeping " per.ods and the increase in their body weight. 
According to $\mathrm{J}$ a g o s z (unpubl. data) in Microtus arvalis the amount of energy obtained from the combustion of a gram of own tissues is about $6 \mathrm{kcal}$. Similar values are given for large mammals and birds by $\mathrm{King} \& \mathrm{Farner}$ (1961) and B laxter (1966). If these indices are adopted for hamsters, a $400 \mathrm{~g}$ animal obtains more than $450 \mathrm{kcal}$ by the combustion of $19 \%$ of its own tissues (K a y s e r, l.c.) whereas the remaining amount of energy needed to survive the winter must be derived from food consumption.

The hamsters observed by $\mathrm{K}$ ayse $\mathrm{r}$ (l.c.) began hibernation in October which ended it in February. Under the climatic conditions of the fields studied in the present work this period must be shifted by one month, since in October all the hamsters were still active and they distinctly higher. The consumption of oxygen by 370 -gram hamsters observed by $\mathrm{K}$ ayse $\mathrm{r}$ (l.c.), but shifted by a month, was therefore used to calculate the flow of energy through the hamster population (Table 8).

\subsection{2. $A D M R$ and Out-of-nest Activity}

$A D M R$ formed the basis for construction of the daily energy budget $(D E B)$ (Grodziński \& Górecki, 1967; Hansson \& Grodziński, 1970; Grodziński \& W under, 1975). The closed-system Morrison respirometer used in this study limited the size of the chambers in which an animal was placed during measurements. Although the hamsters were examined in large, 20-litre chambers containing nest material and food, their locomotor activity was restricted. It is then probable that the value of $A D M R$ is somewhat underestimated. V is inescu (1968) made similar measurements in four seasons but on a small number of animals. The daily metabolic rhythm obtained by this authoress much resembled that found in the present study, but the metabolism - unfortunately the measuring method was not given - was distinctly higher. The consumption of oxygen by 370 -gram hamsters at $23^{\circ} \mathrm{C}$ was about $1.4 \mathrm{cc} / \mathrm{g} \mathrm{hr}$. Rectal temperature was measured in the same 12 hamsters, but as the measuring method was different, the temperature of these animals was naturally lower than that obtained in the present work.

Since the measurement of $A D M R$ includes bioth sleep and rest periods and the activity periods, the costs of thermoregulation outside the nest chamber was added to its value for the time period during which the hamster was active. It was assumed in accordance with measurements that the body temperature in hamsters does not fall during the intervals between periods of hibernation.

The ambient temperature obtained for the winter was converted acc. 
Table 8

Daily energy budget of hamster population.

\begin{tabular}{|c|c|c|c|c|c|c|c|c|c|c|c|c|c|}
\hline Parameters of $D E B$ 's & Jan. & Febr. & March & April & May & Jane & July & Aug. & Sept. & Oct. & Nov. & Dec. & References \\
\hline $\begin{array}{l}\text { Duration of interruped } \\
\text { sleep in } \% \text { of month (f) }\end{array}$ & 53.0 & 48.3 & 27.7 & 0 & 0 & 0 & 0 & 0 & 0 & 0 & 63.0 & 77.7 & Kayser, 1961 \\
\hline $\begin{array}{l}\text { Duration of activity } \\
\text { in } \% \text { of day }(1-f-g)\end{array}$ & 6.3 & 6.3 & 6.3 & 15.0 & 17.0 & 20.0 & 25.0 & 27.0 & 30.0 & 30.0 & 6.3 & 6.3 & $\begin{array}{l}\text { This paper } \\
\text { Molga, } 1958\end{array}$ \\
\hline $\begin{array}{l}\text { Ambient temperature } \\
\text { in }{ }^{\circ} \mathrm{C} \text { during activity }\end{array}$ & 3.4 & 3.0 & 2.6 & 2.3 & 8.9 & 14.4 & 17.2 & 15.2 & 11.9 & 5.4 & 6.0 & 4.4 & recalculated \\
\hline $\begin{array}{l}\text { Cost of reproduction } \\
\text { kcal/day female in } \\
\text { reprodution period }\end{array}$ & 0 & 0 & $\mathbf{0}$ & 4.5 & 18.5 & 0 & 0 & $\begin{array}{l}\text { eventu } \\
\quad 4.5\end{array}$ & $\begin{array}{l}\text { ally } \\
18.5\end{array}$ & 0 & 0 & 0 & This paper \\
\hline Average body wt in $g$ & 462.7 & 511.1 & 559.0 & 600.0 & $\begin{array}{l}132.9^{1} \\
601.4^{2}\end{array}$ & 242.8 & 268.1 & 287.3 & 304.6 & 336.0 & 384.5 & 419.2 & $\begin{array}{l}\text { Mohr et al } \\
\text { 1973. This } \\
\text { paper }\end{array}$ \\
\hline Density - animals/ha & 8.7 & 7.5 & 6.3 & 6.1 & $\begin{array}{r}20.8^{1} \\
5.3^{2}\end{array}$ & 19.1 & 17.4 & 15.6 & 13.9 & 12.2 & 11.0 & 9.8 & This paper \\
\hline$D E B$ (kcal/animal day) & 20.5 & 22.3 & 30.3 & 46.0 & 38.5 & 36.9 & 36.5 & 37.9 & 40.2 & 44.2 & 15.8 & 10.8 & This paper \\
\hline Respiration (kcal/ha day) & 178.5 & 166.9 & 190.8 & 220.5 & 602.3 & 704.9 & 636.7 & 592.1 & 559.4 & 539.9 & 173.4 & 105.9 & This paper \\
\hline
\end{tabular}

1 All animals, 2 Adult animals 
to Molga (1958) and the author's own data (Table 7). The nest chambers being situated at a depth of $1.2-2.0 \mathrm{~m}$, as shown by field observations, so that the temperatures for the depth of $1.6 \mathrm{~m}$ were used for conversions, in which the effect of snow cover was also taken into account ( $F$ or mozov, 1946). The mean temperature at the time of maximum activity was used to calculate the correction for thermoregulation in the summer (Table 7, Fig. 6). The costs of out-of-nest thermoregulation were estimated using the data concerning the animals' activity (Fig. 6), the equation of relationship between metabolism and temperature (Section 3.9) and also K a y s e r's (1959) data.

\subsubsection{Energetics in the Period of Pregnancy and Lactation}

The reproduction season (pregnancy and lactation) is particularly expensive as regards energy ( $\mathrm{Kaczmarski}, 1966$; $\mathrm{Trojan} \mathrm{\&} \mathrm{Woj-}$ ciechowska, 1967; Migula, 1969; Grodziński \& Wunder, 1975). It has been assumed that over $80 \%$ of females take part in reproduction, which is not an exceptional proportion in cricetines $(\mathrm{Fre} \mathrm{nch}$, Stoddart \& Bobek, 1975), and calculated from the field data concerning reproduction and the data given by $\mathrm{Mohr}$ et al. (1973) that a female produces $93 \mathrm{~g}$ of embryos. The calorific values of such young rodents is about $1.1 \mathrm{kcal} / \mathrm{g}$ ( $\mathrm{G}$ o r e c k i, 1965). Consequently, the energetic value of the whole litter is $102.3 \mathrm{kcal}$. In order to produce such a number of young in 18-20 days of pregnancy, the female must additionally consume about $135 \mathrm{kcal}$. The mean assimilation coefficient assumed here for various foods is $76 \%$ (Górecki \& Grygielska, 1975). In order to spread this value uniformly over the period of month, $4.5 \mathrm{kcal} / \mathrm{reproducing}$ female or, more conveniently, $1.98 \mathrm{kcal} /$ average individual of population must be added to the daily energy budget of each day of April, for this is when reproduction occurs.

The period of lactation, which in hamsters lasts for about 18 days (Moh r et al., l.c.; S a moš, 1975) is much more expensive energetically. However, as early as the einghth day of life the young hamsters begin to take additional food, which gradually replaces the share of milk in their diet. It is therefore very difficult to establish to what degree mother's milk satisfies the energetic requirements during the growth of young. It has been assumed here that these animals increase their weight by $40 \mathrm{~g}$ (from $10 \mathrm{~g}$ to $50 \mathrm{~g}$ ) from mother's milk alone. The calorific value of such hamsters has been assumed to be $1.25 \mathrm{kcal} / \mathrm{g}$ (G ó r e cki, 1965). The energetic value of the growth is $465 \mathrm{kcal}$ for the whole litter. All this energy comprised in milk must be produced by the female during the first, little more than ten days of lactation. Even if the efficiency of milk production reaches about $90 \%$ (M a y nard \& Loos li, 
1962) and the coefficient of assimilation of this food by young is similar, a female must consume about 574 kcal extra during a dozen days or so. Thus, $18.5 \mathrm{kcal}$ must be added to the daily budget of each lactating female for each day of May or $8.14 \mathrm{kcal} /$ day to that of each animal of the population. The respiration of young has been omitted in this calculation, because their energy expenses are at the cost of mother's milk.

Such extra daily energy expenditure is very considerable, the more so, because it is much higher in the first several days of lactation. At that time practically no high-energy foodstuffs occur in fields. It seems that just at the time of reproduction females make use of the food supplies gathered in the burrows and left uneaten after the winter. This is supported by the fact that the food stored markedly exceeds the total energy expenditure in the winter and that in the course of the present study remains of food supplies collected in the preceding year were found in hamsters' burrows as late as the early summer. The utilization of a portion of the supplies in the reproduction season may in part account for the enormous effort these animals make to gather such an excessive amount of food in the autumn.

\subsubsection{Construction of Daily Energy Budget $(D E B)$}

As can be seen from the preceding considerations, $D E B$ of the hamster consists of several components:

(1) fraction of hibernation ( $f$ ) - naturally only in winter months; in order to avoid computing the dissipation of energy over a whole month, but only that in an average day, it was assumed for simplification that the percentage of sleep is identical in each day of a given month (Table 8);

(2) stay of animal in the nest ( $g$ ), the basis for which was $A D M R$ at $20^{\circ} \mathrm{C}$ (Daniel, 1964; Grodziński \& Górecki, 1967; Górecki, 1968; Hanss on \& Grodziński, 1970);

(3) thermoregulation out of nest (activity) $1-f-g$ ). It was assumed that in the winter, when the hamster stays in the burrow all day, it is absent from the nest chamber for only about 1.5 hours (i.e. $6.25 \%$ of the day). A very drastic reduction of the time of activity in the winter was observed in many rodents ( $\mathrm{S}$ a in t Girons, 1966; Grodzin$\mathrm{ski} \&$ Górecki, 1967). During this short time of true activity. e.g. feeding in the store-chamber, thermoregulation was computed on the basis of the actual soil temperature at a depth of $1.6 \mathrm{~m}$ (Tables 7 ard 8).

Hibernation was calculated from the equation of relationship between metabolism at the time of this process and body weight given by 
K a y s e $\mathrm{r}(1959,1961)$ and the fraction ( $f)$ of continuous "sleep" (Table 8). In its final form this part of the budget was

$$
M(\mathrm{kcal} / \mathrm{g} \text { day })=0.002 \mathrm{f}(\mathrm{W}: 1000)^{-0.06}
$$

On the other hand, the dissipation of energy at the time of active life was calculated on the basis of relation

$$
M(\mathrm{kcal} / \mathrm{g} \text { day })=18.38 \mathrm{~W}-0.883
$$

The exponent $b$ in the equation of relationship between $A D M R$ and body weight obtained in the present study differed statistically highly significantly $(t=2.9,0.01<p<0.005)$ from the exponent $(0.5)$ found in very many rodents (Hansson \& Grodzinski, 1970; Grodziń$\mathrm{ski} \& \mathrm{French}, 1974)$. DEB was therefore calculated on the basis of the unconverted relationship of $A D M R$ and body weight obtained in this work.

The correction for thermoregulation out of nest (at the time $1-f-g$ ) was introduced into equation (2). Since the intensity of production of heat for thermoregulation was determined to be $5.33 \% / 0{ }^{\circ} \mathrm{C}$ (Section 3.10.), its multiplication by the time of out-of-nest stay and ambient temperature $(t)$ express the respiration during active life

$$
M(\mathrm{kcal} / \mathrm{g} \text { day })=18.38 \mathrm{~W}^{-0.883}[g+(1-f-g)(2-0.05 t)]
$$

The correction for thermoregulation out of nest (at the time $1-f-g$ ) correction for reproduction. Naturally, this correction concerns only two months (May and June), if the population has one litter yearly, or four months (in addition, August and September), if there are two litters (Table 8).

In particular months of the year the two components of the budget (equations 9 and 10) are added together in appropriate proportions to receive the dissipation of energy expressed as the respiration of the animal. The respiration of an average animal of the population during a year was obtained by substituting in this expression the mean body weights from the hamsters actually occurring in the study area in successive months (Table 8, Fig. 4) (Cang u il h e m \& M a r x, 1973).

The costs of maintenance of an individual thus calculated are lowest in November and December, because the animals "sleep" for a large part of the time (Table 8). The highest respiration is observed in April (46 kcal/g day), mainly because the weight of hamsters is very high and an additional amount of energy connected with reproduction is added to the budget. Despite lactation, in May $D E B$ is only $38.5 \mathrm{kcal} / \mathrm{g}$ day, because lactation lasts relatively short and the mean value for this month is greatly influenced by the energy budgets of juveniles, whose body weight is low.

In order to obtain the value of the respiration of the whole population during the year, the indivdiual budgets of average hamsters of given 
months were multiplied by the density of hamsters in the study area at that time (Table 8 , Figs 2 and 4). The energy requirement of hamsters increases from March to June and then begins to decrease in connection with a fall in the density of the population (Fig. 11). The lowest energy requirement naturally occurs in the winter months, when the hamsters hibernate continuously for about $70 \%$ of the time (Table 8, Fig. 11).

The total yearly respiration of the hamster population is $1.444 \times 10^{5}$ $\mathrm{kcal} / \mathrm{ha}$, of which $2.461 \times 10^{4} \mathrm{kcal} / \mathrm{ha}$ falls to 5 months with hibernation, or in the period active life this population dissipates about $83 \%$ of energy for respiration.

\subsubsection{Verification of the Daily Energy Budget of Hamsters}

In order to check hamsters' $D E B$ thus constructed, the values obtained in the present study were compared with those calculated from the equation

$$
D E B(\mathrm{kcal} / \mathrm{g} \text { day })=\left[2.437+f\left(2.3278-0.1164 t_{a}\right)\right] W-0.5
$$

suggested by Grodziński \& Wunder (1975) for rodents and

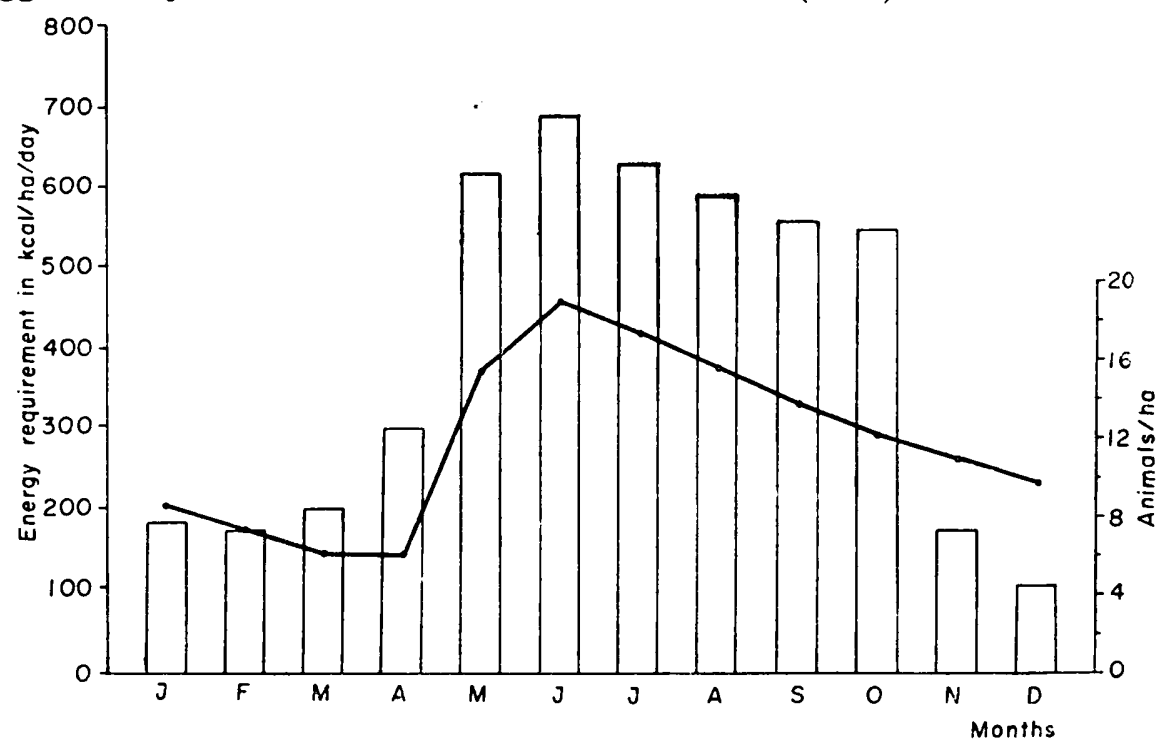

Fig. 11. Cost of maintenance of hamsters (respiration) over a year. Blocks - dissipation of energy in successive months, solid line - density of hamster population.

based on abundant comparative materials. They compared the bidget calculated for Perognathus on the basis of the above formula with the results that $\mathrm{Chew} \& \mathrm{Chew}$ (1970) obtained using $\mathrm{D}_{2}{ }^{18} \mathrm{O}$. This comparison, made for two months, showed quite a surprising agreement, which indicates a great accuracy of formula (12).

The $D E B$ of the hamster was computed using this very equatior. for 
three summer months, July, August and September. The dissipation of energy averages $0.154 \mathrm{kcal} / \mathrm{g}$ day or $44.2 \mathrm{kcal} /$ day for an average animal of the population. An analogous $D E B$ calculated in the present study amounts to $0.133 \mathrm{kcal} / \mathrm{g}$ day or $38.3 \mathrm{kcal} / \mathrm{animal}$ day. Thus the relative error of the budgets computed from Grodzinski \& French's (1974) equation is scarcely $15.4 \%$. This difference is small, for it should be borne in mind that all interspecific equation are, in their very principle, averaged values.

There is also a group of budgets constructed on the basis of $R M R$ (Trojan, 1969; Chew \& Chew, 1969; Grodziński \& Wunder, 1975). The $D E B$ of hamsters was calculated for July from the equation given by $\mathrm{Chew} \& \mathrm{Chew}$ (1970). Such a budget consists of two parts: $E_{m}=E_{r}+E_{a}$, where $E_{m}$ represents the total costs of maintenance, $E_{r}$ the metabolic rate at rest and $E_{a}$ the metabolic rate during activity.

In order to eliminate the costs of activity, which are rather complicated and charged with a grevious error, the values deviating somewhat from the "classical " $R M R$ (G e s a m a n, 1973) were applied here. The basis was here, on the one hand, the minimum metabolic rate of hamsters equal to $0.69 \mathrm{cc} / \mathrm{g} \mathrm{hr}$ and obtained experimentally on resting animals and, on the other hand, the maximum metabolic rate, 2.11 times as high as the previous one (Section 3.9). This last metabolic rate was assumed both for the hours of activity out of the nest and instead of the addition to the metabolic rate for activity. As the ambient temperature in the study area was above $17^{\circ} \mathrm{C}$ in July, it was not needed to add any correction for thermoregulation outside the nest to the mean metabolic rate established at 15 and $20^{\circ} \mathrm{C}$.

$D E B$ thus calculated figures out at $38.1 \mathrm{kcal} / \mathrm{animal}$ day and so it resembles that computed for the same month in the present work (36.6 kcal/animal day). Unfortunately, the calculation of such a budget for winter months is very complicated in hibernators, because it must be made up of very many components. Both comparisons quoted seem however to indicate a fairly great veracity of the energy budget of hamsters calculated in this study. An ideal method for verifying such a budget would certainly be the application of marked water or other isotopic techniques, or simultaneous telemetric measurements of temperature, cardiac rhythm and respiratory rhythm directly under field conditions (Gessaman, 1973). This is however very complicated, involves huge expenses and methodical difficulties - deep burrows would much complicated these measurements or made them simply impossible.

\subsection{Production and Respiration of Hamster Population}

Homoiothermic animals spend a huge majority of assimilated energy 
to cover the costs of maintenance (respiration). M c Neil \& Law to n (1970) collected data concerning production and respiration and their mutual relationship for 12 populations of homoiothermic animals. The efficiency of production of all the populations compared by these authors $(P / A)$ lies within fairly narrow limits of $1.1-2.9 \%$. The mean efficiency from all these populations is about $1.7 \%$. Gliwicz (1973) calculated the value of production efficiency for a population of Proechimys in an analogous way and obtained as much as $4.73 \%$.

The respiration, production and assimilation of the hamster population under study are illustrated in Table 9 . The values given were used to calculate the efficiency of production; it is very high in the hamster population and, coming to $7.2 \%$, markedly exceeds the results obtained by other authors (Table 9). Grodziński \& French (1974) express the relationship between production and respiration by means of an equation based on a rich material of 24 non-hibernating rodent species.

Table 9

Parameters of energy balance of hamster population.

\begin{tabular}{ll}
\hline Respiration, $R$ & $1.198 \times 10^{5} \mathrm{kcal} / \mathrm{ha} 7$ months (activity period) $+2.46 \times 10^{4} \mathrm{kcal} / \mathrm{ha}$ \\
Production, $P$ & 5 months (hibernation period) $=1.445 \times 10^{5} \mathrm{kcal} / \mathrm{ha}$ year \\
& $\begin{array}{l}P_{r}=1034 \mathrm{~g} / \mathrm{ha} \text { year; } P=5435 \mathrm{~g} / \mathrm{ha} \text { year; } \Sigma p=6469 \mathrm{~g} / \mathrm{ha} \\
\text { Assimilation, } A\end{array}$ \\
$\begin{array}{l}\text { Consumption, } C \\
\text { Efficiency of }\end{array}$ & $\begin{array}{l}1.557 \times 10^{5} \mathrm{kcal} / \mathrm{ha} \text { year } \\
\text { production, } \%\end{array}$ \\
$P / R, \% \%$ & $P / A=7.20 ; P / C=5.04$ \\
\hline
\end{tabular}

${ }^{1}$ Calorific value $(1.74 \mathrm{kcal} / \mathrm{g})$ from Fleharty \& Choate, 1973.

If the value of respiration obtained in the present study is substituted in this equation, the value of production thus received is lowered by as much as $50 \%$. McNeil \& Lawton (1970) give an analogous formula describing the relationship between production and respiration. If, in turn, the respiration of hamsters is substituted in it, the actual production determined in the present work appears to be about 4 times as high. As previously, the calorific values of body tissues of Sigmodon were used here to convert the biomass into energetic values (Fleharty \& Choate, 1973).

Grodzinski \& French (1974) also compute production efficiency as $P / R$; obtained in this way for the hamster population, it is very high $(7.8 \%)$ and exceeds even the maximum values given by these authors for Apodemus and Sigmodon (respectively, 6.1 and 6.0\%). The fact that the efficiency in the hamster population calculated by the foregoing methods is evidently higher than in populations of non- 
hibernating animals seems quite natural, for the period of hibernation of hamsters permits an enormous reduction in the costs of maintenance under particularly unfavourable environmental conditions.

\subsection{Energetics of Continuously and Seasonally Active Animals}

If we compare the costs of maintenance calculated from energy budgets. for very various groups of animals, much differing in size but active throughout the year, the dissipation of energy appears to be independent of season.

$\mathrm{G} \mathrm{ę} \mathrm{b} \mathrm{c} \mathrm{z} \mathrm{y} \mathrm{n} \mathrm{s} \mathrm{ki} \mathrm{(1965)} \mathrm{found} \mathrm{that} \mathrm{the} \mathrm{respiration} \mathrm{of} \mathrm{the} \mathrm{common} \mathrm{shrew}$ (Sorex araneus) in winter exceeds that in summer of the average by about $24 \%$. R a n d ol ph (1973), who studied the energetics of Blarina populations, obtained similar figures. The mean values obtained by him for two populations differing in size were higher by about $30 \%$ in winter. G ó r e cki $(1968,1969)$ found that in Clethrionomys glareolus and Apodemus agrarius the summer budgets were higher on the average only by $9.9 \%$ than the winter ones.

Hansson \& Grodziński (1970) demonstrated that in Microtus agrestis the dissipation of energy in summer is $13.8 \%$ higher than in winter and $10.6 \%$ higher than in autumn, these value being at that established for an average vole in the population in the given season. Fleharty \& C h o a t e (1973), who studied the bioenergetics of a population of relatively large Sigmodon hispidus, wrote that the energetic cost of maintenance of this animal in winter is higher only by about $23 \%$.

Lastly, W e in e r (1975) computed that the respiration of a 22-kilo roedoe in summer is only $20 \%$ higher and that of a 25 -kilo roebuck $17 \%$ higher than in winter. Analogous differences in consumption are about $30 \%$ for the female and only $12 \%$ for the male.

Then, as can be seen from all these examples, the dissipation of energy in most of the examined populations of animals that are continuously active all the year round is very similar. The greatest differences between winter and summer do not, as a rule, exceed $30 \%$, and in most species are considerably smaller, in spite of drastic changes in weather and food conditions.

On the other hand, the energy expenses connected with the costs of maintenance in seasonally active animals differ diametrically. Unfortunately, as has been mentioned at the beginning, we have at our disposal only very few data.

Tremendous differences in energy requirement over a year were found in three species of the Gliridae (G ę b z yński et al. 1972). The fat dormouse (Glis glis) used $88.7-91.8 \%$ of the yearly energy requirement in the 6-month period of activity. Muscardinus avellanarius dissipated 
about $92 \%$ of the energy in the same period, not unlike Dryomys niedula, which utilized as much as $92.5 \%$ of its yearly energy budget.

The analogous values obtained for the hamster population indicate that in the winter, while hibernating, these rodents dissipate (respiration) only about $17 \%$ of the energy, the rest being spent during their act.ve life.

The calculations for the Gliridae, like those in the present study, ccncern the whole period of hibernation without allowing for short pericds in which the animals were awake. These periods having been allowed for, the energy dissipated during true hibernation was naturally s:ill much lower. K a y s e (1965) observed that in Spermophilus the dissipation of energy in 171 days of hibernation was $70 \mathrm{kcal}$, but in the periods of awakenings, 14 days altogether, the animal spent as much as 580 kcal.

Like hamsters, the Gliridae consume their food supplies gathered in the autumn during the breaks in hibernation (Golley, Rys zkowski \& S okur, 1975). The lower dissipation of energy than in hamsters can be explained in the Gliridae by a greater amount of energy deposited in the form of adipose tissue, e.g. in the grey squirrel fat constituted as much as $40 \%$ of body tissues before hibernation (G ę b c z y ńs ki et $x l$, 1972). Such deposition of adipose tissue, rather expensive in energy (K ing \& Farner, 1961; B laxter, 1966), in turn, causes also an increase in the total energy expenses in the period of activity.

Finally, there is another essential difference between the groups of animals under discussion, namely, the pressure exerted on the ecosystem varies with season in a different way. The continuosly active animals, as a rule, exercise the greatest influence on the ecosystems in the prevernal season and early spring. The destruction of even a small number of plants in the spring may have a tremendous effect on the final yield ( $\mathrm{J} \mathrm{u} \mathrm{d}$ e $\mathrm{n} \mathrm{k}$ o, 1967; T e r til, 1974). On the other hand, hibernators exert the strongest pressure on the agrocenoses in the late summer and autumn.

To sum up, hibernators have a completely different influence upon the ecosystem from that of continuously active animals, in which the daily energy budgets show relatively small fluctuations in different seasons of the year. In summer both groups of animals act in a similar way in the chains of energy flow, whereas in winter hibernators are completely excluded from these chains.

\subsection{Effect of Hamster Population upon Crops}

The production of crops which are potential food for hamsters was calculated on the basis of their average structure in the fields examined and the data concerning the efficiency of different crops ( $\mathrm{N}$ i e w i a d o m- 
ski, 1971; P a wlicki, 1974). Such an »average* hectare offers both substantial foodstuffs (seeds of cereal plants, Vicia faba, maize and sunflower) and green forage (wheat, rye, maize, lucerne, grass and sunflower) to these animals during the year. The yearly yield of green forage averages $56.7 \mathrm{q}$. of dry matter/ha or about $2.27 \times 10^{7} \mathrm{kcal} / \mathrm{ha}$ and that of grain $31.2 \mathrm{q}$. or about $1.40 \times 10^{7} \mathrm{kcal} / \mathrm{ha}$. There is $3.67 \times 10^{7} \mathrm{kcal}$ of food altogether in 1 hectare in a year (vegetative season).

If we assume that the coefficient of assimilation is $70 \%$ (mean value from own data and those given by $\operatorname{Erdakov}$, 1972) (Table 9), the whole population of hamsters consumes $1.84 \times 10^{5} \mathrm{kcal} / \mathrm{ha}$ during the 7-month period of active life. This result must however be augmented by the value of foodstuffs uneaten but spoilt, which may be very various and even exceed the consumption by many times ( $\mathrm{T}$ e r t il, 1974; $\mathrm{Z} \mathrm{I} \mathrm{o-}$ $\mathrm{t}$ in, 1975). If hamsters destroy as much food as they eat up, the effect, approximately only $1 \%$, is still relatively small. $\mathrm{Zl}$ ot in (1975) however found that in grass land ecosystems the consumption constitutes scarcely $5 \%$ of the total impact of rodents, whereas the whole rest consists just of these destroyed foods and other effects of these animals resulting in a lowering of the yield.

The impact of hamsters was found to be tremendous in autumn, when in addition to foraging these animals begin to store food. Their provisions consist chiefly of grain (Karaseva \& Shilayeva, 1965; Petzsch, 1965; Walker, 1964) and thus they influence the yield directly at that time. If we assume that each hamsters stores about $15 \mathrm{~kg}$ of food and that at that time (August-October) the mean number of hamsters approaches 14 individuals/ha (Table 8), they all together gather above $200 \mathrm{~kg}$ of food. The mean calorific value of these supplies is about $4 \mathrm{kcal} / \mathrm{g}$, because, as has been mentioned, they consist chiefly of grain, the water content of which is very low. Thus the supplies gathered by hamsters in an area of 1 ha amount to as much as $8.32 \times 10^{5} \mathrm{kcal}$. As the output of grain is about $1.4 \times 10^{7} \mathrm{kcal} / \mathrm{ha} \mathrm{yr}$, the impact of hamsters on the crops in this period is very considerable; it reaches a considerable figure of $5.9 \%$ in their food caches only.

If we increase this figure by adding the estimate of consumption and correcting it using the above-mentioned indices ( $\mathrm{Zlot}$ in, 1975) of the consumption: dectruction ration, the immense impact of hamsters on the grops becomes evident.

As can be seen from the foregoing calculation, hamsters can "compete" fairly successfully with man in harvesting the ultimate crop.

The impact of rodents on different ecosystems does not, as a rule, exceed 2\% (Chew \& Chew, 1970; Ges s a man, 1974; Golley, Ryszkowski \& Sokur, 1975). A $20 \%$ decrease in crops was observ- 
ed only in the case of Microtus arvalis (Ryszkowski, Goszczyiski \& Truszkowski, 1973). This situation was however exceptional, taking place during a heavy outbreak of these rodents. Among the materials presented by Golle y et al. (1975) there is, in addition, a case of the $12 \%$ impact of Peromyscus, but this impact has been determined only in relation to grass seeds, the production of which is relatively low.

Even if we use the values concerning the primary production accessikle to animals ( $\mathrm{C} \mathrm{h} \mathrm{ew} \mathrm{\&} \mathrm{Ch} \mathrm{e} \mathrm{w,} \mathrm{1970),} \mathrm{most} \mathrm{ecosystems} \mathrm{are} \mathrm{utilized} \mathrm{by} \mathrm{ro-}$ dents, as a rule, in $1.6-5.8 \%$.

Againts a backround of these results the findings obtained by $A$ b a t $\lambda$ rov, Rakova \& S e redneva (1975) are particularly relevant. They concern the impact of sousliks, which, like hamsters, are only seasonally active, on grassland ecosystems. The pressure of these animals was extremely high, ranging from 10 up to $38 \%$ in different years. These values by many times exceed both the values calculated in the present study and those listed by $\mathrm{Chew} \& \mathrm{Chew}(1970)$ and Golle y et al. (1975) for different rodent populations. This was connected, on the one hand, with a very great abundance of sousliks (36-66 individuals/ha) and, on the other hand, with the low productivity of these ecosystems and their great accessibility to these animals. Neither of these facts however explains completely such a tremendous impact of sousliks on the ecosystem. Being seasonally active animals, sousliks seem to have to secure food supplies for the rest of the year, apart from their normal consumption, in a relatively short time, which, naturally, brings about this great overestimation of their total impact of the ecosystem, examined only during the period of active life.

In considering the impact of hamsters on agrocenoses, one must not omit their beneficial influences. The first of them results from their subterraneous mode of life. While digging their tunnels, hamsters dislodge huge amounts of soil and from a very great depth at that. G olle y et al. (1975) present a comparison of the amounts of soil removed by different animals, but it does not include the hamster. The knowledge of burrows of hamsters ( $\mathrm{K}$ a rase va \& Shila ye va, 1965) permits the calculation which shows that, digging its burrows, a hamster must transport about $1 \mathrm{~m}^{3}$ of soil yearly, often from a depth approaching $2 \mathrm{~m}$. Such dislodgments of soil are of enormous importance to the distributicn of chemical compounds. A b a turov \& $\mathrm{Zubkova}$ (1969) write that $1500 \mathrm{~kg}$ of soil/ha yr removed by Citellus in the steppe contained $j \mathrm{~kg}$ of $\mathrm{Na}, 77 \mathrm{~kg}$ of $\mathrm{Ca}, 122 \mathrm{~kg}$ of $\mathrm{Al}, 18 \mathrm{~kg}$ of $\mathrm{S}$, and many other equally important biogens.

Another problem is the fertilization of soil by hamster populations. An average 400 -gram hamster, which takes only $10.5 \mathrm{~g}$ of dry mattır in 
food daily, returns $2.5 \mathrm{~g}$ of faeces and urine to the ecosystem. The yearly energy budget of these rodents indicates that at a mean assimilation coefficient the consumption is $2.2 \times 10^{5} \mathrm{kcal} / \mathrm{ha}$ (Table 9). Thus, about $15 \mathrm{~kg}$ of faeces and urine must be returned to each hectare of cultivated fields during a year. Here we must add huge food stores, which are probably never used up (Section 4.2.3.). If only $25 \%$ of the food cache remains unused, which the amount of organic matter which returns to the ecosystem increases by about $30 \mathrm{~kg} / \mathrm{ha} \mathrm{yr}$. This amount is small in comparison with the data given by $\mathrm{Kucheruk}$ (1963) for steppe rodents of Eurasia, which produced up to $250 \mathrm{~kg}$ of excreta/ha. It is however very rich in nitrogen (D ro z d $\dot{z}, 1968$ ) and accelerates the circulation of matter very much; it may also have an effect on the increase in vegetable production. Ulehla, Pelikan \& $\mathrm{Zichova}$ (1974) found that lucerne around the burrows of hamsters, especially old ones, was much higher and had its biomass markedly larger, which was naturally due to the particularly intense "fertilization « of the field in in the vicinity of these burrows.

The harmful impact of hamsters on crops may also be compensated to a small degree by the destruction of invertebrates noxious to agriculture, but vegetable foodstuffs prevail decidedly in the diet of these rodents (G ór e c k i \& Gr y g i e ls ka, 1975).

The range of hamsters in Poland is fairly wide, for they occur in the whole south-eastern part of the country up to the line connecting the towns Zielona Góra, Poznań, Płock and Białystok (S u r d a ck i, 1963, $1971,1973)$. In spite of their discontinuous distribution, the impact of hamsters on agrocenoses seems to be very great by standards of the whole country.

Acknowledgements: The author wishes to express his heartfelt thanks to the menagers and workers of the Experimental Station, Institute of Tillage, Fertilization and Pedology, at Borusowa, in general, and to Eng. Z. P y tlakowski and Eng. $\mathrm{M}$. $\mathrm{H}$ a c haj, in particular, for making this study on a hamster population in their fields possible and for their being very helpful throughout the study. $H e$ is also extremely grateful to Mr. S. Rojkowski for his invaluable help with all field work and to Dr. R. Andrzeje wski, Dr. W. Grodziński, Dr. M. Gębczyń$\mathrm{ski}$, Dr. A. B a r t ke and all collegaues for critical remarks.

\section{REFERENCES}

1. A baturov B. D., Rakova M. V. \& Seredneva T. A., 1975: Vozdejstvie malyh suslikov na produktivnost rastitelnosti polupustyni severnogo Prikaspija. [In: »Rol životnych $\mathrm{v}$ funkcjonovanii ekosystem«, Eds. R. J. Zlotin, J. A. Isakov \& K. S. Hodašova]. Izd. Nauka. MOIP.: 15-18 Moskva.

2. Abaturov B. D. \& $\mathrm{Zubk}$ ova L. V., 1969: Vlijanie malyh suslikov (Citellus pygmaeus Pall.) no vodno-fizyčeskie svcistva soloncovyh počv polupustyni Zavolžija. Počvovedenije, 10: $59-69$.

3. Andrzejewski R. \& Gliwicz J., 1969: Standard method of density estimation of Microtus arvalis (Pall.) for the investigation of its productivity. Small Mamm. Newslet., 3: 45-53. 
4. B laxter K. L., 1966: Przemiany energetyczne u przeżuwaczy. Państw. Wyd. Roln. i Leśne: 1-374. Warszawa.

5. Bobek B., 1973: Net production of small rodents in a deciduous forest. Acta theriol., 18, 21: 403-434.

6. Canguilhem B. \& M a r x Ch., 1973: Regulation of the body weight of the European hamster during the annual cycle. Pflügers Arch., 338: 169-175.

7. Canguilhem B., Schieber J. P. \& Koch A., 1973: Rythme circannuel pondéral du hamster d'Europe (Cricetus cricetus). Arch. Sci. Physiol., 27, 1: $67-90$.

8. Chew R. M. \& Chew A. E., 1970: Energy relationship of the mammals of a desert shrub (Larrea tridentata) community. Ecol. Monogr., 40, 1: 1-21.

9. Daniel M., 1964: Temperature and humidity in the nest of Clethrionomys glareolus observed in continuous experiment. Acta Soc. Zool. Bohemoslov., 38: 278-279.

10. Drożd A., 1968: Digestibility and assimilation of natural foods in small rodents. Acta theriol., 13, 21: 367-389.

11. Erdakov L. N., 1972: Potrieblenie energii i koeficent utylizaci u obyknovennovo homjaka i vodjanoj krysy. Ekologija, 1: 66-69.

12. F e ri a n c ovà - M a s à rovà $\mathrm{Z}$. \& H a n àk V., 1965: Cicavce. Vyd. Slov. Akad. Vied: 1-332. Bratislava.

13. Fle harty E. D. \& Choate J. R., 1973: Bioenergetic strategies of the cotton rat Sigmodon hispidus. J. Mammal., 54, 3: 680-692.

14. Formozov A. N., 1946: Rol snežnogo pokrova v žizni mlekopitajuščih i ptic. Mater. k pozn. fauny i flory SSSR, 5, 20: 1-141.

15. French N. R., Stoddart D. M. \& B obek B., 1975: Patterns of demography in small mammal population. [In: «Small mammals: their productivity and population dynamics«, Eds.: F. B. Golley, K. Petrusewicz, L. Ryszkowski]. Cambr. Univ. Press: 73-103.

16. Gessaman J. A., 1973: Ecological energetics of homeotherms. Mon. Ser. Utah State Univ. Press, 20: 1-155. Logan, Utah.

17. Gębczyńs i M., 1965: Seasonal and age changes in the metabolism and activity of Sorex araneus $\mathrm{L}$ in $\mathrm{n}$ a e u s, 1758. Acta theriol., 10, 22: 303-331.

18. Gębczyński M., Górecki A. \& Drożdz A., 1972: Metabolism, food assimilation and bioenergetics of three species of dormice (Gliridae). Acta theriol., 17, 21: 271-294.

19. Gliwicz J., 1973: A short characteristics of a population of Proechimys semispinosus ( $\mathrm{T}$ omes, 1860) - a rodent species of the tropical rain forest. Bull. Acad. Sci., B, Cl II, 21, 6: 413-417.

20. Gliwicz J., Andrzejewski R., Bujalska G. \& Petrusewicz K., 1968: Productivity investigation of an island population of Clethrionomys glareolus. I. Dynamics of cohorts. Acta theriol., 13, 23: 401-413.

21. Golle y F. B., PetrusewiczK. \& R yszkowski L., (Eds.), 1975: Small mammals: their productivity and population dynamics. Cambridge Univ. Press: 1-451. Cambridge.

22. Golley F. B., Ryszkowski L. \& Sokur J. T., 1975: The role of small mammals in temperate forests, grasslands and cultivated fields. [In: *Small mammals: their productiviy and population dynamics«, Eds.: F. B. Golley., K. Petrusewicz, L. Ryszkowski], Cambridge Univ. Press: 223-243. Cambridge.

23. G6recki A., 1965: Energy values of body in small mammals. Acta theriol., 10, 23: 333-352. 
24. Górecki A., 1968: Metabolic rate and energy budget in the bank vole. Acta theriol., 13, 20: $341-365$.

25. Gor ecki A., 1969: Metabolic rate and energy budget of the striped field mouse. Acta theriol., 14, 14: 181-190.

26. Go r e cki A., 1975: Kalabukhov-Skvartzov respirometer and resting metabolism rate measurement. [In: wMethods of ecological bioenergetics». Eds.: W. Grodziński., R. Klekowski., A. Duncan], Blackwell Sci. Publ.: 310-314. Oxford.

27. Górecki A. \& Grygielska M., 1975: Consumption and utilization of natural foods by the common hamster. Acta theriol., 20, 18: 237-246.

28. Gorecki A. \& Wołek J., 1975: Thermoregulation in common hamster. Acta theriol., 20, 23: 297-300.

29. Grodziński W. \& Górecki A., 1967: Daily energy budgets of small rodents. [In: *Secondary productivity of terrestrial ecosystems«, Ed. K. Petrusewicz], Państw. Wyd. Nauk.: 295-314. Warszawa.

30. Grodziński W. \& French N. R., 1974: Production and respiration in population of small mammals. [In: «First Intern. Theriol. Congress-Moscow«], vol. 1: 206. Publ. House Nauka.

31. Grodziński W., Klekowski R. \& Duncan A., (Eds.), 1975: Methods for ecological bioenergetics. Blackwell Sci., Publ.: 1-367, Oxford.

32. Grodziński W. \& Pucek Z. (Eds.), 1975: The role of large herbivore mammals in woodland ecosystems. Pol. Ecol. Studies, 1, 2: 1-142. Warszawa.

33. Grodziński W. \& Wunder B. A., 1975: Ecological energetics of small mammals. [In: Small mammals: their productivity and population dynamics $\alpha$, Eds.: F. B. Golley, K. Petrusewicz, L. Ryszkowski], Cambridge Univ. Press: 173-204. Cambridge.

34. Hans S on L. \& Grodziński W., 1970: Bioenergetics parameters of the field vole Microtus agrestis L. Oikos, 1, 21: $76-82$.

35. Jude nko E., 1967: The loss of yield in a crop of sweet corn (Zea mays L.) following the complete destruction of some plants at an early stage by brown rats (Rattus norvegicus Berk.). Pest Articles and News Summ., 13, 4: 412-413.

36. $\mathrm{Kaczm}$ a r s i F., 1966: Bioenergetics of pregnancy and lactation in the bank vole. Acta theriol., 11, 19: 409-417.

37. Karaseva E. B. \& Shila yeva L. M., 1965: The structure of hamster burrows in relation to its age and the season. Bull. MOIP, Biol., 70, 6: 30-39. [In Russian with English summ.].

38. K a y s e $\mathrm{r}$ Ch., 1939: Echanges respiratoires des hibernants réveilles. Ann. Physiol., Physicochim. Biol., 15,5: 1087-1219.

39. K a y s e $\mathrm{C}$., 1959: Les échanges respiratoires du hamster ordinaire (Cricetus cricetus) et du lérot (Eliomys quercinus) en hibernation. C. R. Soc. Biol., 153: $167-170$.

40. Kayse r Ch., 1961: The physiology of natural hibernation. Pergamon Press: 1-325. Oxford, London, New York, Paris.

41. K a y s e r Ch., 1965: Hibernation. [In: »Physiological mammalogy«, Eds. W. V. Mayer, van Gelder, Academic Press]: 179-296. New York, London.

42. Kayser Ch., 1971: Le dépense d'énergie des hibennants au cours du cycle circannien. Biol. Compt. Rend., 165, 5: 1145-1147.

43. K ing J. R. \& F a r n e r D. S., 1961: Energy metabolism, thermoregulation and body temperature. [In: *Biology and comparative physiology of birds $\alpha$. II, Ed.: A. J. Marshall]: 215-288. New York.

44. K le iber M., 1961: The fire of life. J. Wiley: 1-454. New York. 
45. Kowa lski K. (Ed.), 1964: Klucze do oznaczania kręgowców Polski. V. Ssaki Mammalia. Państw. Wyd. Nauk.: 1-280. Warszawa.

46. Ku cheruk V. V., 1963: Vozdeistve travojadnyh mlekopitajušcih na produktivnost travostoja stepi i ih znacenie $\mathrm{v}$ obrazovanii organiceskoj casti stepnyh počv. Tr. MOIP, 10: 157-191.

47. L o r d R. D. Jr., 1959: The lens as an indicator of age in cottontail rabbits. J. Widl. Manage., 23, 3: 358-360.

48. L y ma n C. P. \& D a we A. R., (Eds.), 1960: Mammalian hibernation. Bull. Mus. Comp. Zool., 124: 1-549: Harvard.

49. M a la n A. \& $\mathrm{H}$ ild we in G., 1969: Thermorégulation en embiance chaude d'un hibernant le hamster d'Europe (Cricetus cricetus) comparaison avec le rat blanc. Arch. Sci. Physiol., 23, 2: 153-181.

50. M a y a rd L. A. \& Loosli J. K., 1962: Animal nutrition. McGraw-Hill Book Comp.: 1-533. New York, London.

51. McArthur R. H. \& Connel1 J. H., 1966: The biology of populations. J. Wiley: 1-200. New York, London, Sydney.

52. M c Neil S. \& L a w t on J. H., 1970: Annual production and respiration in animal populations. Nature, 225, (5231): 472-474.

53. Migula P., 1969: Bioenergetics of pregnancy and lactation in European common vole. Acta theriol., 14, 13: 167-179.

54. Mohr U., Schuller H., Reznik G., Althoff J. \& Page N., 1973: Breeding of European hamsters. Lab. Anim. Sci. 23, 6: 799-802.

55. M o lg a M., 1958: Meteorologia rolnicza. Państw. Wyd. Roln. i Leśne: 1-571. Warszawa.

56. Morrison P. \& Grodziński W., 1975: Morrison respirometer and determination of ADMR. [In: »Methods of ecological bioenergetics «, Eds. W. Grodziński, R. Klekowski \& A. Duncan]. Blackwell Sci. Publ.: 300-310. Oxford, London.

57. N i e wia domski W. (Ed.), 1971): Podstawy agrotechniki. Państw. Wyd. Roln. i Leśne: 1-738. Warszawa.

58. Pawlicki S. (Ed.), 1974: Rocznik statystyczny województwa krakowskiego 1974. Woj. Urząd Statyst.: 1-493. Kraków.

59. Pelikán J., 1967: Resorption rate in embryos of four Apodemus species. Zool. Listy, 19, 2: 93-102.

60. Pelikán J., 1970: Embryonic resorption in Microtus arvalis (Pall.). Zool. Listy, $16,4: 325-342$.

61. PetrusewiczK., 1966: Production vs, turnover of biomass and individuals. Bull. Acad. Pol. Sci., Cl II, 9: 545-553.

62. Petrusewicz K., 1970: Dynamics and production of the hare population in Poland. Acta theriol., 15, 26: 413-445.

63. PetrusewiczK., Andrzejewski R., Bujalska G. \& Gliwicz J., 1968: Productivity investigation of an island population of Clethrionomys glareolus (S c hr e be r, 1780). IV. Production. Acta theriol., 13, 26: 435-445.

64. Petrusewicz K. \& Hansson L., 1975: Biological production in small mammal populations. [In: «Small mammals: their productivity and population dynamics«, Eds. F. B. Golley, K. Petrusewicz \& L. Ryszkowski], Cambridge Univ. Press: 153-173. Cambridge.

65. Petrusewicz K. \& M a cFadyen A., 1970: Productivity of terrestrial animals. Principles and methods. Blackwell Sci. Publ.: 1-190. Oxford. 
66. P o p ov V. A., 1960: Mlekopitajuščie Volžsko-Kamskogo kraja. Izd. Kazan, FAN, SSSR: 1-432. Kazan.

67. Petzs ch H., 1952: Der Hamster. Akad. Verlag: 1-56. Leipzig.

68. R a n dolph J. C., 1973: Ecological energetics of a homeothermic predator, the short-tailed shrew. Ecology, 54, 5: 1166-1187.

69. Ryszkowski L., Goszczynski J. \& Truszkowski J., 1973: Trophic relationships of the common vole in cultivated fields. Acta theriol., 18, 7: $125-165$.

70. Saint Girons M. Ch., 1966: Le rythme circadien de l'activité chez les mammiféres holarctiques. Mem. Mus. Nat. Hist. Nat., Zool., 40: 101-187.

71. S a moš V. M., 1975: Materialy po rozmnożeniju i plodovitosti abyknovennogo homjaka (Cricetus cricetus L.). Ekologija, 5: 97-98.

72. Stroganova A. S., 1954: Mlekopitajušce stepnogo i polupustynnogo Zavolža. Tr. ZIN, AN SSRR, 16: 1-485.

73. Surdacki S., 1963: The northern limit of the range of Cricetus cricetus ( $\mathrm{L}$ in $\mathrm{n}$ a e $\mathrm{u} \mathrm{s}, 1758$ ) in eastern Poland. Acta theriol., 6, 1: 309-310. [In Polish with English summ.].

74. Surdacki S., 1971: The distribution and ranges of the European hamster Cricetus cricetus (Linn a e us, 1758) in Poland. Annls Univ. M. Curie-Skłodowska, 26, 12: 265-285. [In Polish with English summ.].

75. Surdacki S., 1968: The dynamics of population density of Citellus suslicus (Gueldenstaedt, 1770) at Sławęcin, in the years 1961-1966. Annls Univ. M. Curie-Sklodowska, 23, 9: 223-247.

76. Surdacki S., 1973: The north and the south border of the range and the area of occurrence of European hamster Cricetus cricetus (L innaeus, 1758) in Poland. Przegl. zool., 17, 1: 86-88. [In Polish with English summ.].

77. Tertil R., 1974: Wplyw żerowania nornika (Microtus arvalis Pall.) na plonowanie pszenicy ozimej. Biul. IOR, 57: 385-391.

78. Trojan P., 1969: An ecological model of the cost of maintenance of Microtus arvalis (Pall.). [In: »Energy flow through small mammal populations «, Eds. F. B. Golley, K. Petrusewicz \& L. Ryszkowski], Pol. Sci. Publ.: 113-122. Warszawa.

79. Trojan P. \& Wojcdechowska B., 1967: Resting metabolism rate during pregnancy and lactation in the European common vole-Microtus arvalis. Ekol. pol., $A, 15,44: 811-817$.

80. Ülehla J., Pelikan J. \& Zichova L., 1974: Rodent burrowing activity and heterogeneity of a lucerne stand. Zool. Listy, 23, 2: 113-121.

81. W a lker E. P., 1964: Mammals of the world. J. Hopkins Press, 2: 647-1500. Baltimore.

82. W einer J., 1975: Model of the energy budget of an adult roe deer. [In: "The role of large herbivore mammals in woodland ecosystem «, Eds. W. Grodziński, Z. Pucek], Pol. ecol. Studies, 1, 2: 103-119. Warszawa.

83. Weiner J. \& Górecki A., 1974: Field registration of the animals activity using infra-red light. Wiad. ekol., 20, 3: 287-291. [In Polish with English summ.].

84. Weiner J. \& Górecki A., 1975: Radiotelemetry used in deep body temperature measurements of animals. Wiad. ekol., 21, 3: 233-241. [In Polish with English summ.].

85. Visinescu N., 1968: The homeostasis and rhythms of the energetic metabolism, body temperature and motor activity in hamster (Cricetils cricetus L.). Rev. Roum. Biol., Zool., 13: 2: 139-144. 
86. Vohralik V., 1974: Biology of the reproduction of the common hamst:r, Cricetus cricetus (L.). Vest. Cs. spol. zool., 38, 3: 228-240.

87. Vohralík V., 1975: Postnatal development of the common hamster Crücenus cricetus (L.) in captivity. Rozpr. Ceskoslov. Akad. Ved, 85, 9: 3-48.

88. Zlotin R. J., 1975: Ocenka vozdejstvia Životnyh - fitofagov na perviěntju produkcju lugovo-stepnogo pastbišča. [In: »Rol životnych $v$ funkcjonovauii ekasystem« Eds. R. J. Zlotin, J. A. Isakov \& K. S. Hodašova]. Izd. Nausa MOIP: 18-22. Moskva.

Accepted, August 15, 1976.

\section{Andrzej GORECKI}

\section{PRZEPEYW ENERGII PRZEZ POPULACJE CHOMIKOW}

\section{Streszczenie}

Badania nad przepływem energii przez populację chomików Cricetus criceius (L innaeus, 1758) oraz ich wpływem na uprawy prowadzono na 128 ha pól leących w dolinie Wisły $-80 \mathrm{~km}$ od Krakowa (Ryc. 1). Liczebność dorosłych chomikıw okreslano wiosną i jesienią każdego roku przez liczenie czynnych nor (Tabela 1). Srednie roczne zagęszczenie dorosłych zwierząt wynosiło 8,5/ha. Po uwzględnieriu młodych zwierząt, których ilość oszacowano z liczby embrionów cakkowite :agęszczenie wynosi rocznie średnio 12,4 chomików/ha (Ryc. 2). Na podstawie :ależności ciężarów ciała i ciężarów soczewek oka chomików ustalono struktırę wiekową tych gryzoni (Ryc. 3, Tabele 2, 3, 4). Z kolei pozwoliło to na ułożenie tabel życia populacji chomików (Tabela 5, Ryc. 4).

Produkcja populacji chomików wynosi w ciągu roku $6,5 \mathrm{~kg} / \mathrm{ha}, \mathrm{z}$ czego $1 \mathrm{a}$ produkcję rozrodu przypada tylko $1,03 \mathrm{~kg} / \mathrm{ha}$. Rotacja biomasy całej populacji j!st równa 1,40, a średnia długość życia wynosi około 7 miesięcy.

Rytm aktywności dobowej chomików był zarówno latem, jak i jesienią dwuszczytowy. Latem aktywność poza norą trwała około 3,5 godziny, a jesienia ponıd 6 godzin na dobę (Ryc. 6). Głębokie temperatury ciała, mierzone telemetryczrie u chomików eksponowanych w 15 i $20^{\circ} \mathrm{C}$ nie różniły się między sobą i całą dobę oscylowaly pomiędzy $37 \mathrm{i} 38^{\circ} \mathrm{C}$ (Ryc. 10). Sredni metabolizm dobowy chomikow w $15^{\circ} \mathrm{C}$ wynosil 1,00 , a w $20^{\circ} \mathrm{C} 1,08 \mathrm{~cm}^{3} \mathrm{O}_{2} / \mathrm{g}$ godz, przy czym metabolizm maksymalny (1,45 $\mathrm{cm}^{3} \mathrm{O}_{2} / \mathrm{g}$ godz) przewyższał minimalny 2,11 razy (Tabela 6, Ryc. 8, 9). Zależność metabolizmu $\left(M-\mathrm{cm}^{8} \mathrm{O}_{2} / \mathrm{g}\right.$ godz) i ciężaru ciała $(W)$ miała postać:

$$
M=162,9 \mathrm{~W}^{-0,883} \quad \text { (Ryc. 7) }
$$

Ocentiono dobowe budżety energetyczne populacji chomikow w cyklu roczn:m (Tabele 7, 8). Taki budżet (respiracja) waha się od 105,9 w grudniu lo $704,9 \mathrm{kcal} / \mathrm{ha}$ /dzień $\mathrm{w}$ czerwcu (Ryc. 11). Asymilacja populacji wynosi $1.56 \times .05$ kcal/ha/rok, a stosunek produkcji do niej wynosil 7,2\% (Tabela 9).

$\mathrm{W}$ oparciu o średnią strukturę zasiewów i wydajność produkcji oraz o liczebność chomików i ich konsumpcję, udało się oszacować wpływ tych gryzoni ra ekosystemy. Latem ich wpływ powodowany konsumpcją jest niewielki i nie pr:ekracza 1\%. Natomiast jesienią, gdy chomiki gromadza przysłowiowe zapasy rokarmowe, ich wpływ wzrasta do około $6 \%$ nie wliczając $w$ to pokarmów zniszc:onych. 